\title{
Methane at Svalbard and over the European Arctic Ocean
}

\author{
Stephen M. Platt ${ }^{1}$, Sabine Eckhardt ${ }^{1}$, Benedicte Ferré ${ }^{2}$, Rebecca E. Fisher ${ }^{3}$, Ove Hermansen ${ }^{1}$, Pär Jansson ${ }^{2}$, \\ David Lowry $^{3}$, Euan G. Nisbet ${ }^{3}$, Ignacio Pisso ${ }^{1}$, Norbert Schmidbauer ${ }^{1}$, Anna Silyakova ${ }^{2}$, Andreas Stohl ${ }^{1}$, \\ Tove M. Svendby ${ }^{1}$, Sunil Vadakkepuliyambatta ${ }^{2}$, Jürgen Mienert ${ }^{2}$, and Cathrine Lund Myhre ${ }^{1}$ \\ ${ }^{1}$ NILU - Norwegian Institute for Air Research, P.O. Box 100, 2027 Kjeller, Norway \\ ${ }^{2}$ CAGE-Centre for Arctic Gas Hydrate, Environment and Climate, Department of Geosciences, \\ UiT The Arctic University of Norway, 9037 Troms $\varnothing$, Norway \\ ${ }^{3}$ Department of Earth Sciences, Royal Holloway, University of London, Egham, UK
}

Correspondence: Stephen M. Platt (sp@nilu.no)

Received: 15 June 2018 - Discussion started: 5 July 2018

Revised: 12 October 2018 - Accepted: 31 October 2018 - Published: 5 December 2018

\begin{abstract}
Methane $\left(\mathrm{CH}_{4}\right)$ is a powerful greenhouse gas. Its atmospheric mixing ratios have been increasing since 2005. Therefore, quantification of $\mathrm{CH}_{4}$ sources is essential for effective climate change mitigation. Here we report observations of the $\mathrm{CH}_{4}$ mixing ratios measured at the Zeppelin Observatory (Svalbard) in the Arctic and aboard the research vessel (RV) Helmer Hanssen over the Arctic Ocean from June 2014 to December 2016, as well as the longterm $\mathrm{CH}_{4}$ trend measured at the Zeppelin Observatory from 2001 to 2017. We investigated areas over the European Arctic Ocean to identify possible hotspot regions emitting $\mathrm{CH}_{4}$ from the ocean to the atmosphere, and used state-of-the-art modelling (FLEXPART) combined with updated emission inventories to identify $\mathrm{CH}_{4}$ sources. Furthermore, we collected air samples in the region as well as samples of gas hydrates, obtained from the sea floor, which we analysed using a new technique whereby hydrate gases are sampled directly into evacuated canisters. Using this new methodology, we evaluated the suitability of ethane and isotopic signatures $\left(\delta^{13} \mathrm{C}\right.$ in $\left.\mathrm{CH}_{4}\right)$ as tracers for ocean-to-atmosphere $\mathrm{CH}_{4}$ emission. We found that the average methane / light hydrocarbon (ethane and propane) ratio is an order of magnitude higher for the same sediment samples using our new methodology compared to previously reported values, 2379.95 vs. 460.06 , respectively. Meanwhile, we show that the mean atmospheric $\mathrm{CH}_{4}$ mixing ratio in the Arctic increased by $5.9 \pm 0.38$ parts per billion by volume (ppb) per year $\left(\mathrm{yr}^{-1}\right)$ from 2001 to 2017 and $\sim 8 \mathrm{pbb} \mathrm{yr}^{-1}$ since 2008, similar to the global trend of $\sim 7-8 \mathrm{ppb} \mathrm{yr}^{-1}$. Most large excursions from the baseline $\mathrm{CH}_{4}$ mixing ratio over the European Arctic Ocean are due to
\end{abstract}

long-range transport from land-based sources, lending confidence to the present inventories for high-latitude $\mathrm{CH}_{4}$ emissions. However, we also identify a potential hotspot region with ocean-atmosphere $\mathrm{CH}_{4}$ flux north of Svalbard $\left(80.4^{\circ} \mathrm{N}\right.$, $12.8^{\circ} \mathrm{E}$ ) of up to $26 \mathrm{nmol} \mathrm{m}^{-2} \mathrm{~s}^{-1}$ from a large mixing ratio increase at the location of $30 \mathrm{ppb}$. Since this flux is consistent with previous constraints (both spatially and temporally), there is no evidence that the area of interest north of Svalbard is unique in the context of the wider Arctic. Rather, because the meteorology at the time of the observation was unique in the context of the measurement time series, we obtained over the short course of the episode measurements highly sensitive to emissions over an active seep site, without sensitivity to land-based emissions.

\section{Introduction}

The atmospheric mixing ratio of methane $\left(\mathrm{CH}_{4}\right)$, a powerful greenhouse gas with global warming potential $\sim 32$ times higher than carbon dioxide $\left(\mathrm{CO}_{2}\right)$ (Etminan et al., 2016), has increased by over $150 \%$ since pre-industrial times (Hartmann et al., 2013; IPCC, 2013). The $\mathrm{CH}_{4}$ mixing ratio increased significantly during the 20th century, and then stabilized from 1998 to 2005 . This brief hiatus ended in 2005 and the mixing ratio has been increasing rapidly ever since (Hartmann et al., 2013; IPCC, 2013). For example, the global mean $\mathrm{CH}_{4}$ mixing ratio was 1953 ppb in 2016, an increase of $9.0 \mathrm{ppb}$ compared to the previous year (WMO, 2017). An $\sim 8-9 \mathrm{ppb}$ increase per year in atmospheric $\mathrm{CH}_{4}$ is equivalent 
to a net emissions increase of $\sim 25 \mathrm{Tg} \mathrm{CH}_{4}$ per year (Worden et al., 2017).

The reasons for the observed increases in atmospheric $\mathrm{CH}_{4}$ are unclear. A probable explanation, identified via shifts in the atmospheric $\delta^{13} \mathrm{C}$ in $\mathrm{CH}_{4}$ isotopic ratio compared to the Vienna Pee Dee Belemnite standard $\left({ }^{13} \mathrm{C}\right.$ in $\mathrm{CH}_{4}$ vs. VPDB) is increased $\mathrm{CH}_{4}$ emissions from wetlands, both in the tropics (Nisbet et al., 2016) as well as in the Arctic (Fisher et al., 2011). For example, Nisbet et al, 2016 report that the increases in $\mathrm{CH}_{4}$ concentrations since 2005 coincided with a negative shift in $\delta^{13} \mathrm{C}$ in $\mathrm{CH}_{4}$. Because fossil fuels have $\delta^{13} \mathrm{C}$ in $\mathrm{CH}_{4}$ above the atmospheric background, this negative shift implies changes in the balance of sources and sinks. I.e. even if fossil fuel emissions are partly responsible for the increases in the $\mathrm{CH}_{4}$ atmospheric mixing ratio since 2005, their relative contribution has decreased. This suggests a role for emissions from methanogenic bacteria in wetland soils and/or ruminants, since these do have strongly negative $\delta^{13} \mathrm{C}$ in $\mathrm{CH}_{4}$ compared to ambient values and fossil sources, or changes in the sink strength (reaction with hydroxyl radicals, $\mathrm{OH})$.

There is also evidence that the fraction of $\mathrm{CH}_{4}$ emitted by fossil fuels is higher than previously thought, based on mixing ratios of co-emitted ethane (Worden et al., 2017; Dalsøren et al., 2018), suggesting that current emission inventories need revaluating. As well as increases in the average global $\mathrm{CH}_{4}$ mixing ratio, ethane, often co-emitted with anthropogenic $\mathrm{CH}_{4}$ has also increased. However, this ethane increase is weaker and less consistent than that of $\mathrm{CH}_{4}$ itself (Helmig et al., 2016), indicating another source than fossil fuel emissions contibutes to recent $\mathrm{CH}_{4}$ increases, as well as a lack of consensus as to which sources are predominantly responsible for the increase in the $\mathrm{CH}_{4}$ mixing ratio. Accordingly, it is clear that although a total net $\mathrm{CH}_{4}$ flux to the atmosphere of $\sim 550 \mathrm{Tg} \mathrm{CH}_{4} \mathrm{yr}^{-1}$ is well constrained via observations (Kirschke et al., 2013), the relative contribution of the individual sources and sinks responsible for the rapid increases since 2005 is uncertain (Dalsøren et al., 2016; Nisbet et al., 2016; Saunois et al., 2016). This makes future warming due to $\mathrm{CH}_{4}$ emissions difficult to predict. Therefore, the recent observed increase in the atmospheric $\mathrm{CH}_{4}$ mixing ratio has led to enhanced focus and intensified research to improve our understanding of $\mathrm{CH}_{4}$ sources, particularly in response to global and regional climate change.

In this study, we focus on the Arctic and investigate the impact of oceanic $\mathrm{CH}_{4}$ sources on atmospheric $\mathrm{CH}_{4}$. The Arctic region is of great importance since surface temperatures are rising at around $0.4^{\circ} \mathrm{C}$ per decade, twice as fast as the global average warming rate (Chylek et al., 2009; Cohen et al., 2014), and it contains a number of $\mathrm{CH}_{4}$ sources sensitive to temperature changes. For example, high-latitude $\left(>50^{\circ} \mathrm{N}\right)$ wetlands are a significant source of Arctic $\mathrm{CH}_{4}$, contributing as much as $15 \%$ to the global $\mathrm{CH}_{4}$ budget (Thompson et al., 2017). Furthermore, Dlugokencky et al. (2009), Bousquet et al. (2011), and Rigby et al. (2008) link anomalous
Arctic temperatures in 2007 to elevated global $\mathrm{CH}_{4}$ mixing ratios in the same year due to increased high-latitude wetland emissions. Other Arctic $\mathrm{CH}_{4}$ sources sensitive to temperature include forest and tundra wildfires, likely to increase in frequency and intensity with warmer temperatures and more frequent droughts (Hu et al., 2015), and thawing permafrost and tundra (Saunois et al., 2016).

Oceanic $\mathrm{CH}_{4}$ sources, are small globally $\left(2-40 \mathrm{Tg} \mathrm{yr}^{-1}\right)$ compared to terrestrial sources such as wetlands (153$227 \mathrm{Tg} \mathrm{yr}^{-1}$ ) and agriculture (178-206 $\mathrm{Tg} \mathrm{yr}^{-1}$ ) (Kirschke et al., 2013; Saunois et al., 2016). However, oceanic $\mathrm{CH}_{4}$ fluxes are highly uncertain and may be particularly important in the Arctic due to the extremely large reservoirs of $\mathrm{CH}_{4}$ under the seabed, and the potential for climate feedbacks. For example, gas hydrates (GHs), an ice-like substance formed in marine sediments, can store large amounts of $\mathrm{CH}_{4}$ under low-temperature and high-pressure conditions within the gas hydrate stability zone (GHSZ) (Kvenvolden, 1988). Around Svalbard the GHSZ retreated from 360 to $396 \mathrm{~m}$ over a period of around 30 years, possibly due to increasing water temperature (Westbrook et al., 2009), though numerous other sources dispute this: for example, Wallmann et al. (2018) suggest that the retreating GHSZ is due to geologic rebound since the regional ice sheets melted (isostatic shift). The climate impact of decomposing GHs is poorly constrained, in part due to large uncertainties in their extent (Marín-Moreno et al., 2016). Though Kretschmer et al. (2015) give a recent estimate of $116 \mathrm{Gt}$ carbon stored in hydrates under the Arctic Ocean, other estimates vary widely, from 0.28 to $512 \mathrm{Gt}$ carbon (Marín-Moreno et al., 2016, and references therein).

Presently, little of the $\mathrm{CH}_{4}$ entering the water column over active geologic seep sites and at the edge of the GHSZ around Svalbard reaches the atmosphere. $\mathrm{CH}_{4}$ fluxes to the atmosphere were below $2.4 \pm 1.4 \mathrm{nmol} \mathrm{m}^{-2} \mathrm{~s}^{-1}$ in summer 2014 at a shallow seep site (50-120 m depth) off Prins Karls Forland (Myhre et al., 2016) and below $0.54 \mathrm{nmol} \mathrm{m}^{-2} \mathrm{~s}^{-1}$ for all waters less than $400 \mathrm{~m}$ deep around Svalbard in 2014-2016 (Pisso et al., 2016). Such low ocean-atmosphere $\mathrm{CH}_{4}$ fluxes, even over strong sub-sea sources, may be due to the efficient consumption of $\mathrm{CH}_{4}$ by methanotrophic bacteria (Reeburgh, 2007). However, the extent to which microbiology or any other factor mitigates the climate impact of sub-sea seep sites across the wider Arctic region, and whether it will continue to do so, is uncertain. Furthermore, previous studies do not report observed fluxes since ocean-atmosphere emissions were too low to produce observable changes in atmospheric $\mathrm{CH}_{4}$ mixing ratios. Either, flux constraints were estimated by determining the maximum flux possible which would not exceed observed variations in the measured atmospheric $\mathrm{CH}_{4}$ mixing ratio (Myhre et al., 2016; Pisso et al., 2016), or fluxes were inferred based on dissolved $\mathrm{CH}_{4}$ concentrations at the ocean surface (Myhre et al., 2016; Pohlman et al., 2017). Therefore, while this suggests ocean-atmosphere fluxes are very low around Svalbard, at least for the periods so far stud- 
ied, the true size of the $\mathrm{CH}_{4}$ flux from sub-sea seeps and gas hydrates remains unknown.

Finally, while not sensitive to temperature changes, anthropogenic emissions are a significant source of highlatitude $\mathrm{CH}_{4}$ emissions. For example, a significant fraction of the world's oil and gas is extracted in Russia, for which Hayhoe et al. (2002) estimate $\mathrm{CH}_{4}$ leakage rates as high as $10 \%$. This leak rate is likely to have declined substantially in recent years to around $2.4 \%$ or $27.7 \mathrm{Mt}$ in 2015 (UNFCC, 2018), likely due to increased recovery of the associated gas $\left(\mathrm{CH}_{4}\right.$-rich gas produced during the fossil fuel extraction process) and hence less flaring in the region (Höglund-Isaksson, 2017). The Norwegian coastal shelf also has a large number of facilities related to oil and gas extraction, though fugitive emissions are much lower than for Russia at only $0.04 \mathrm{Mt}$ (UNFCC, 2018).

Here we report observations of $\mathrm{CH}_{4}$ at Zeppelin Observatory from 2001 to 2017, and over the European Arctic Ocean from 2014 to 2016 measured on board the research vessel (RV) Helmer Hanssen. To identify and quantify potential oceanic $\mathrm{CH}_{4}$ sources under present climate conditions we scanned relevant areas of the Arctic Ocean to identify hotspot regions. In this time period the RV Helmer Hanssen passed in close proximity to known sub-sea $\mathrm{CH}_{4}$ seeps, the edge of the GHSZ at several locations, Arctic settlements such as Longyearbyen (Svalbard), the Norwegian and Greenland coasts, and oil and gas facilities in the Norwegian Sea. Using these data combined with other available information, i.e. carbon dioxide $\left(\mathrm{CO}_{2}\right)$, FLEXPART modelled source contributions, data from the Zeppelin Observatory, we observe and explain episodes of increased $\mathrm{CH}_{4}$ over the Arctic Ocean, thereby evaluating the emission inventories and investigating whether seeps or decomposing hydrates influence atmospheric $\mathrm{CH}_{4}$ mixing ratios. We also utilize the $\delta^{13} \mathrm{C}$ in $\mathrm{CH}_{4}$ vs. V-PDB and atmospheric mixing ratios of light hydrocarbons (LHC, i.e. ethane, propane) in the atmosphere above and around known sub-sea seep sites and compare this to the composition of GHs from sediment core samples. For this comparison, we developed a new methodology to obtain GH samples for laboratory analysis.

\section{Methodology}

\subsection{Methane measurements at the Zeppelin Observatory}

The Zeppelin Observatory $\left(78.91^{\circ} 540 \mathrm{~N}, 11.88^{\circ} \mathrm{E}\right)$ is located at the Zeppelin Mountain ( $476 \mathrm{~m}$ above sea level, a.s.l.) on the island of Spitsbergen (the largest island of the Svalbard archipelago, Fig. 1) and has an atmospheric $\mathrm{CH}_{4}$ mixing ratio record dating from 2001. The observatory is a regional background site, far from local and regional sources (Yttri et al., 2014). Data from Zeppelin contribute to global, regional and national monitoring networks, including the European Evaluation and Monitoring Programme (EMEP), the
Global Atmospheric Watch (GAW), the Arctic Monitoring and Assessment Programme (AMAP), and Advanced Global Atmospheric Gases Experiment (AGAGE). The site is also included in the EU infrastructure project ACTRIS (Aerosols, Clouds and Trace gases Research InfraStructure). In May 2018, Zeppelin was classified as ICOS (Integrated Carbon Observation System) class 1 site for $\mathrm{CO}_{2}, \mathrm{CH}_{4}$ and $\mathrm{CO}$ measurements.

For 2001-2012 we obtained $\mathrm{CH}_{4}$ measurements with a gas chromatography flame ionization detector (GC-FID) system with an inlet $2 \mathrm{~m}$ above the observatory roof (i.e. $478 \mathrm{~m}$ a.s.l.). Sample precision for this system was $\pm 3 \mathrm{ppb}$ at hourly resolution as determined from repeat calibrations against Advanced Global Atmospheric Gases Experiment (AGAGE) reference standards (Prinn et al., 2008). Since April 2012 we have measured $\mathrm{CH}_{4}$ at Zeppelin using a cavity ring-down spectroscope (CRDS, Picarro G2401) at 1 minute resolution with a sample inlet $15 \mathrm{~m}$ above the observatory roof (491 ma.s.l.). We calibrate the CRDS every 3 days against working standards, which we calibrate to National Oceanic and Atmospheric Administration (NOAA) reference standards. For both of these sampling regimes, we sampled the air via a heated inlet with excess airflow (residence time $\sim 10 \mathrm{~s}$ ) and through a Nafion drier to minimize any water correction error in the instruments. The full time series from August 2001 to 2013 was re-processed as a part of the harmonization of historic concentration measurements within the European Commission project, InGOS, archived and documented in the ICOS Carbon portal (ICOS, 2018).

\subsection{Trend Calculations for methane at the Zeppelin Observatory}

We calculated the annual trend in atmospheric $\mathrm{CH}_{4}$ mixing ratio according to Simmonds et al. (2006), whereby the change in atmospheric mixing ratio of a species as a function of time $f(t)$ is fit to an empirical equation combining Legendre polynomials and harmonic functions with linear, quadratic, and annual and semi-annual harmonic terms for $2 \mathrm{~N}$ months of data:

$$
\begin{aligned}
f(t)= & a+b \cdot N \cdot P_{1}\left(\frac{t}{N}-1\right)+\frac{1}{3} \cdot d \cdot N^{2} \\
& \cdot P_{2}\left(\frac{t}{N}-1\right)+\frac{1}{3} \cdot e \cdot N^{3} \cdot P_{3}\left(\frac{t}{N}-1\right) \\
& +c_{1} \cdot \cos (2 \pi t)+s_{1} \cdot \sin (2 \pi t) .
\end{aligned}
$$

An advantage of this methodology is that seasonal variation is accounted for, while fitting parameters $a-e$ yield useful information. For example, $a$ defines the average mole fraction, $b$ defines the trend in the mole fraction and $d$ defines the acceleration in the trend. Coefficients $c_{1}$ and $s_{1}$ define the annual cycles in the mole fraction and $P_{i}$ are the Legendre polynomials of order $i$. 


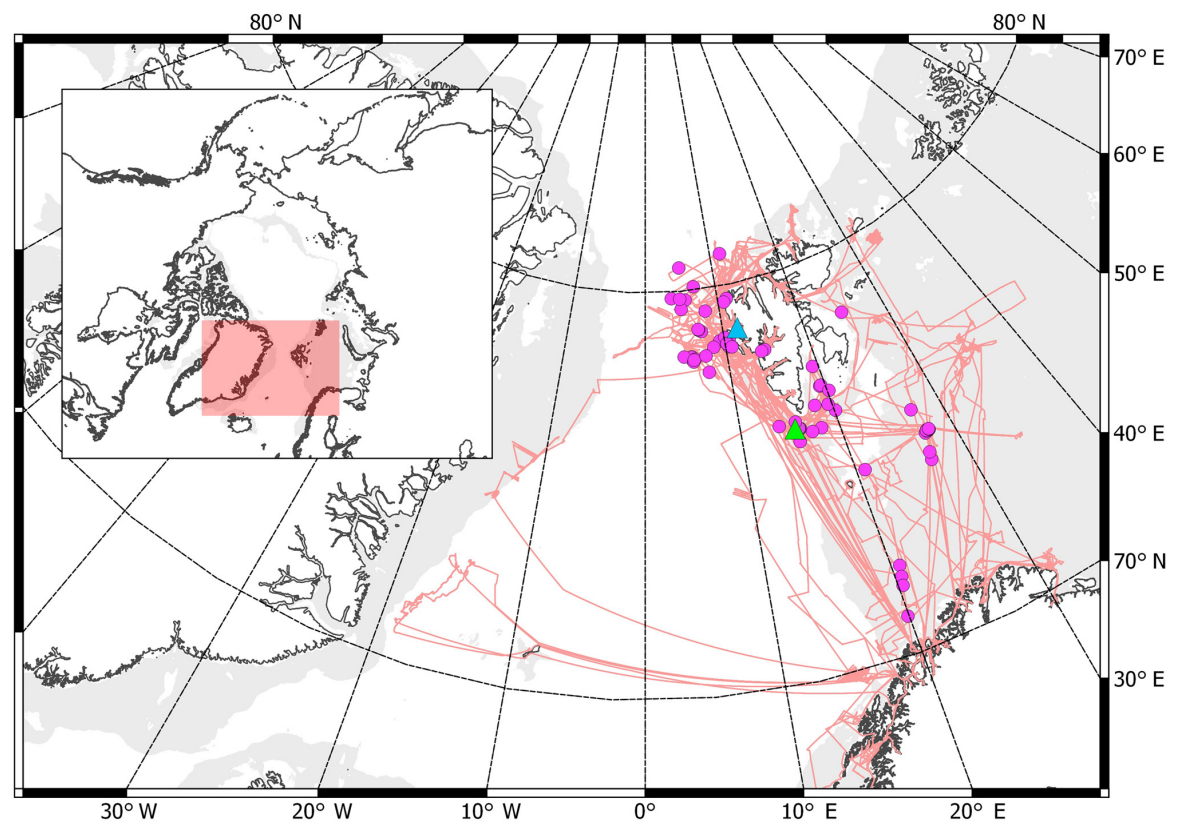

Figure 1. Route of the RV Helmer Hanssen (pink line) in 2014-2016, locations of offline flask samples (violet dots), the Zeppelin Observatory (blue triangle), and the location from which hydrates were collected from the seafloor (green triangle). Light grey shows areas of shallow ocean (100-400 m deep) according to the International Bathymetric Chart of the Arctic Ocean, IBCAO (Jakobsson et al., 2012). Sampling locations included much of the Svalbard coast, the Barents Sea, the Norwegian coast and waters off Greenland. The inset shows the global location of the measurements, with the area of the larger map shown by the shaded region.

\subsection{Atmospheric trace gas measurements at RV Helmer Hanssen}

We obtained near continuous online $\mathrm{CH}_{4}$ and $\mathrm{CO}_{2}$ time series on board the RV Helmer Hanssen using a CRDS (Picarro G2401) from June 2014 to December 2016 (see Fig. 1 for route). The data were collected in a harmonized way with those from the Zeppelin Observatory. The CRDS connects to a heated main sample inlet line with excess airflow and air is sampled through a drier. A multiport valve on the instrument inlets enables switching between sampled air and control samples/working standards. As at the Zeppelin Observatory, we calibrate the CRDS instrument every 3 days with working standards calibrated to National Oceanic and Atmospheric Administration (NOAA) reference standards. The central inlet line on the RV Helmer Hanssen is connected to the top of the mast ( $22.4 \mathrm{~m}$ a.s.l.) located to the fore of the ship exhaust (Fig. 2). Sample residence time is about $10 \mathrm{~s}$. We manually exclude measurements affected by exhaust emissions by excluding data where spikes in the $\mathrm{CO}_{2}$ mixing ratio of $100 \mathrm{ppm}$ above background or higher coincided with perturbations in the $\mathrm{CH}_{4}$ mixing ratio. We observed no correlation between apparent wind direction relative to the bow (i.e. wind experienced by an observer on board), and $\mathrm{CH}_{4}$ mixing ratios after filtering the data in this way (Fig. S1 in the Supplement).
We also collected air samples for offline analysis on board the RV Helmer Hanssen into evacuated stainless steel canisters (see Fig. 1 for sampling locations), using the same sample line as the CRDS system (Fig. 2). We sent the canisters for analysis at the laboratory at NILU where we analysed them with a gas chromatography mass spectrometer (GCMS) system (Medusa, Miller et al., 2008). This instrument detects trace gases including a range of hydrocarbons (e.g. ethane and propane) at the ppt level and is calibrated AGAGE reference standards (Prinn et al., 2008). We separated a fraction of each of the air samples collected in 2014 at the RV Helmer Hanssen into new stainless steel flasks, which we submitted for isotopic analysis $\left(\delta^{13} \mathrm{C}\right.$ in $\mathrm{CH}_{4}$ vs. V-PDB) at Royal Holloway, University of London (RHUL). $\mathrm{CH}_{4}$ and $\mathrm{CO}_{2}$ were first quantified using a CRDS (Picarro G1301) for quality control. Each sample was then analysed, at least in triplicate, using a Trace Gas-IsoPrime CF-GC-IRMS system (Fisher et al., 2011, and references therein), giving an average precision of $0.04 \%$. Finally, in addition to the aforementioned atmospheric parameters, we also collected meteorological and nautical data, e.g. wind speed and wind direction, water temperature, ice cover, and sea state at the RV Helmer Hanssen. 


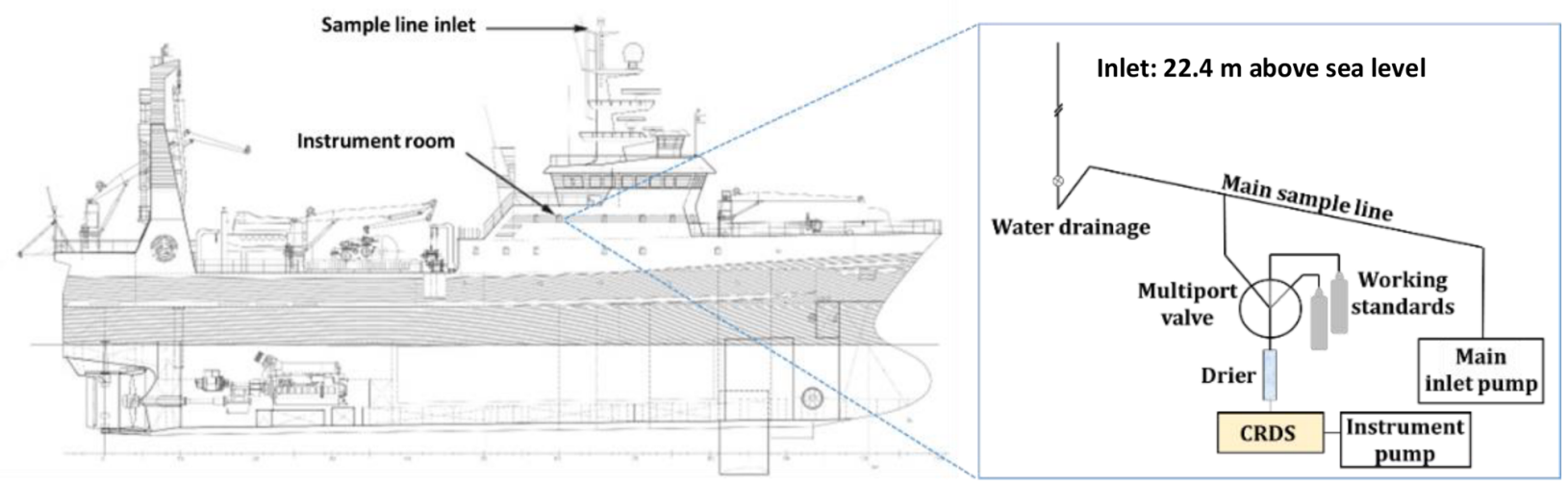

Figure 2. Schematic of the RV Helmer Hanssen showing the location of the sample inlet (to scale) and schematic of instrument room (not to scale).

\subsection{Collection of gas hydrate samples}

We obtained two sediment cores containing GHs from the sea-floor south of Svalbard on 23 May 2015, CAGE 15-2 HH $911 \mathrm{GC}$ and CAGE $15-2 \mathrm{HH} 914 \mathrm{GC}$, at $76.11^{\circ} \mathrm{N}, 15.97^{\circ} \mathrm{E}$ and $76.11^{\circ} \mathrm{N}, 16.03^{\circ} \mathrm{E}$, respectively (Fig. 1). We immediately transferred small $\mathrm{GH}$ pieces $\left(\sim 1 \mathrm{~cm}^{3}\right)$ to an airtight container connected to an evacuated stainless steel flask via stainless steel tubing and a two-way valve. Once the airtight container with the GH sample was sealed, we opened the two-way valve to allow sublimated gas from the sample into the evacuated flask. This sample was then stored for subsequent analysis of light hydrocarbons (LHCs) and $\mathrm{CH}_{4}$ at NILU, using GC-FID and a Picarro CRDS, respectively, as well as $\delta^{13} \mathrm{C}$ at RHUL.

In a widely used GH sampling technique, small hydrate pieces are transferred into glass vials containing an aqueous sodium hydroxide $(\mathrm{NaOH})$ solution and sealed with a rubber stopper (e.g. Smith et al., 2014; Serov et al., 2017). Overpressure due to gases released from the sediments is reduced by exposing the sample to the atmosphere. Our technique, developed as part of this study, offers several advantages over this methodology. Firstly, we avoid artefacts likely to occur using the headspace technique due to repeated exposure to the atmosphere and contamination from the gases initially present in the headspace. Secondly, we do not dissolve the gas samples in solution, which might otherwise change the relative concentrations of the gases since they will have different solubilities in $\mathrm{NaOH}_{(\mathrm{aq})}$. Thirdly, the stainless steel connections in our GH sampling system are certified for pressures up to $120 \mathrm{bar}$ (while the flask itself has a tolerance of $150 \mathrm{bar}$ ), allowing for collection of a larger gas volume. Finally, the sample can be stored indefinitely and transported without gas exchange between the sample and the atmosphere since the closed valve of a stainless steel flask is relatively more secure than a rubber stopper.

\subsection{Atmospheric transport modelling}

We modelled atmospheric transport using a Lagrangian particle dispersion model, FLEXPART v9.2 (Stohl et al., 2005), to produce gridded $\left(0.1^{\circ} \times 0.1^{\circ}\right)$ sensitivity fields for surface (so called "footprint sensitivity") $\mathrm{CH}_{4}$ emissions 20 days backwards in time for both the RV Helmer Hanssen and Zeppelin Observatory for the Northern Hemisphere. Since the RV Helmer Hanssen is a moving platform, we generated receptor boxes at hourly time resolution, or, the time taken to move by $0.5^{\circ}$ latitude or longitude, if this was less than $1 \mathrm{~h}$, along the ship track. Thus, the minimum time resolution was $1 \mathrm{~h}$, increasing to higher time resolution when the ship was moving at relatively high speeds.

FLEXPART footprint sensitivities provide both qualitative and quantitative information. For example, inspection of the footprint provides information about which areas have more influence on measured mixing ratios, even in the absence of numerical emission data. Furthermore, the units of the FLEXPART output are such that the product of sensitivity and flux density yields the mixing ratio change at the receptor (e.g. for sensitivity in units of $\mathrm{kg}^{-1} \mathrm{~m}^{2} \mathrm{~s}^{-1}$ and emission flux densities in $\mathrm{kg} \mathrm{m}^{-2} \mathrm{~s}^{-1}$ ). In this study, we use footprint sensitivities to simulate the influence of terrestrial sources during the 20 days prior to sampling on $\mathrm{CH}_{4}$ mixing ratios, as the product of footprint sensitivity and monthly gridded emission fields.

\subsection{Use of emission inventories}

Bottom-up estimates of anthropogenic $\mathrm{CH}_{4}$ emissions from the main sources are taken from emission inventories, which provide estimations based on national and international activity data, sector-by-sector emission factors, and gridded proxy information for activity distribution. In this work, we used for anthropogenic emissions GAINS-ECLIPSE version 5a (Stohl et al., 2015, http://www.iiasa.ac.at/web/home/ research/researchPrograms/air/ECLIPSEv5a.html, last ac- 


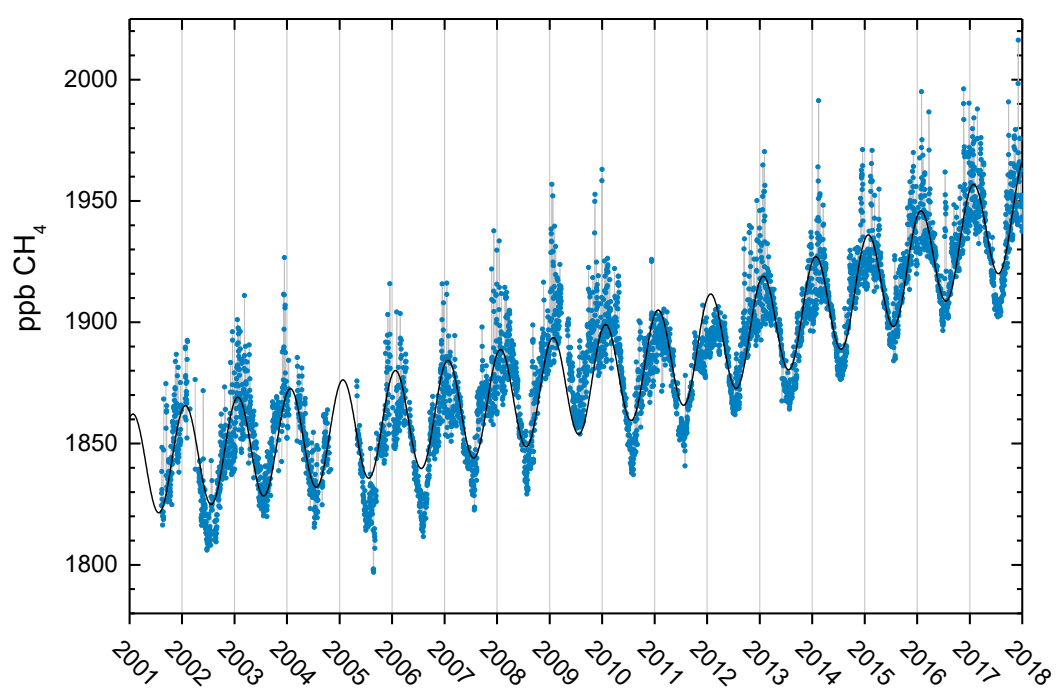

Figure 3. Observations of daily averaged $\mathrm{CH}_{4}$ mixing ratio for the period 2001-2017 at the Zeppelin Observatory. The blue dots are daily mean mixing ratios in ppb, and the black solid line is the empirically fitted $\mathrm{CH}_{4}$ mixing ratio (Eq. 1).

cess: 21 November 2018) for the latest available year, 2010. For biomass burning emissions, we used data from the Global Fire Emissions Database, GFEDv4, (Randerson et al., 2017) for the year 2014. For wetland emissions we used estimates from the global vegetation and land surface process model LPX-Bern (Spahni et al., 2011; Stocker et al., 2014; http://www.climate.unibe.ch/, last access: 21 November 2018), also for 2014.

\section{Results and discussion}

\subsection{Long-term methane trends at Zeppelin Observatory}

As discussed in Sect. 2.1 the location of the Zeppelin Observatory on an Arctic mountain is ideal for studying longterm hemispheric changes since the site is far from local and regional $\mathrm{CH}_{4}$ sources and pollution. Nevertheless, there are episodes with long-range transport of pollution from lower latitudes from Russia, Europe, and the US (Stohl et al., 2007, 2013; Yttri et al., 2014). The daily mean observations of $\mathrm{CH}_{4}$ at Zeppelin since the start in 2001 together with empirical (Eq. 1) depict a strong increase from late 2005, with a trend of $5.9 \pm 0.3 \mathrm{ppb} \mathrm{yr}^{-1}$ over the period 2001-2017 (Fig. 3). There was a new record level of $1938.9 \mathrm{ppb}$ in $\mathrm{CH}_{4}$ annual mean in 2017, an increase of $6.8 \mathrm{ppb}$ since 2016, and as much as $86.4 \mathrm{ppb}$ increase since 2005 . The global mean for 2016 was $1853 \mathrm{ppb}$ (WMO, 2017), while the level at Zeppelin was $1932.1 \mathrm{ppb}$, reflecting large-scale latitudinal gradients with highest concentrations in the Arctic. Since 2010, the average yearly increase has been $8 \mathrm{ppb}$ at Zeppelin. We find no significant difference between trends when calculated on a seasonal basis.
Dalsøren et al. (2016) addressed the atmospheric $\mathrm{CH}_{4}$ evolution over the last 40 years using the OsloCTM3 model, and found that for Zeppelin, wetland emissions and fossil gas emissions are the main contributors in summer and winter, respectively. The highest ambient $\mathrm{CH}_{4}$ mixing ratio measured at Zeppelin (Fig. 3) was on 5 December 2017, at $2016.3 \mathrm{ppb}$. The transport pattern for that day shows a strong influence from Russian industrial pollution from northwestern Siberia (NILU, 2018). Fugitive emissions from Russian gas installations are a possible source of this $\mathrm{CH}_{4}$. However, on this particular day, both carbon monoxide (CO) and $\mathrm{CO}_{2}$ levels were also very high, possibly implicating industrial pollution.

There is most likely a combination of reasons for the recent strong increases in $\mathrm{CH}_{4}$ and the dominating reason is not clear. A probable explanation is increased $\mathrm{CH}_{4}$ emissions from wetlands, both in the tropics as well as in the Arctic region, in addition to increases in emission from the fossil fuel industry. Ethane and $\mathrm{CH}_{4}$ are emitted together from fossil oil and gas sources, and a slight decrease or stable level in ethane at Zeppelin (Dalsøren et al., 2018) supports the hypothesis that wetland emission changes are a large contributor to increasing $\mathrm{CH}_{4}$ mixing ratios. Emissions from the ocean could also be an important factor, which we investigate in depth in this study (Sects. 3.3-3.4).

\subsection{Emissions}

The main high-latitude source regions for anthropogenic $\mathrm{CH}_{4}$ emission are the oil and gas fields in Arctic northwestern Russia and western Siberia, particularly in the Pechora and $\mathrm{Ob}$ River regions (Fig. 4a). These regions are responsible for $20 \%$ of the world's natural gas production 
(a)

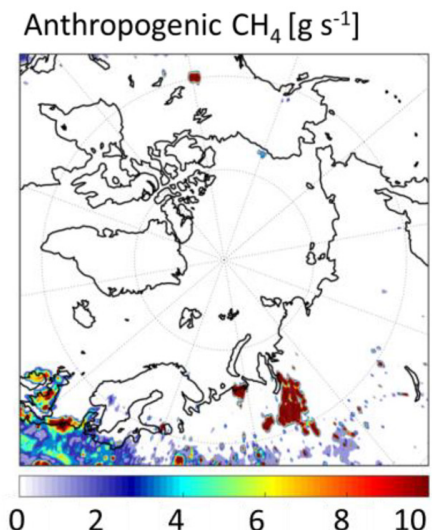

Wetland $\mathrm{CH}_{4}\left[\mathrm{~g} \mathrm{~s}^{-1}\right]$

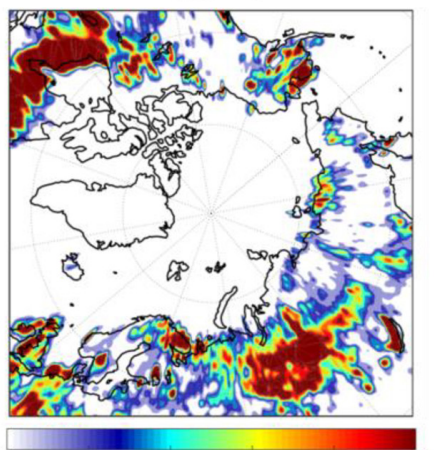

$\begin{array}{lllll}0.2 & 0.4 & 0.6 & 0.8 & 1.0\end{array}$
Biomass burning $\mathrm{CH}_{4}\left[\mathrm{~g} \mathrm{~s}^{-1}\right]$

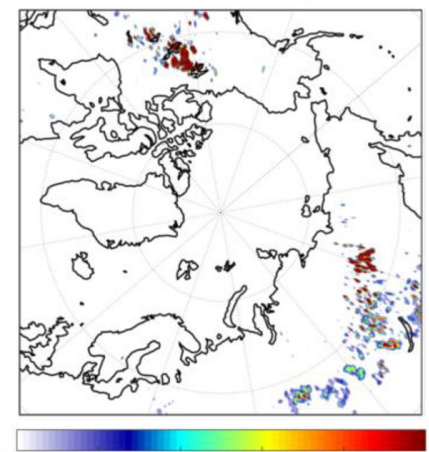

$\begin{array}{lllll}0.2 & 0.4 & 0.6 & 0.8 & 1.0\end{array}$

(b)

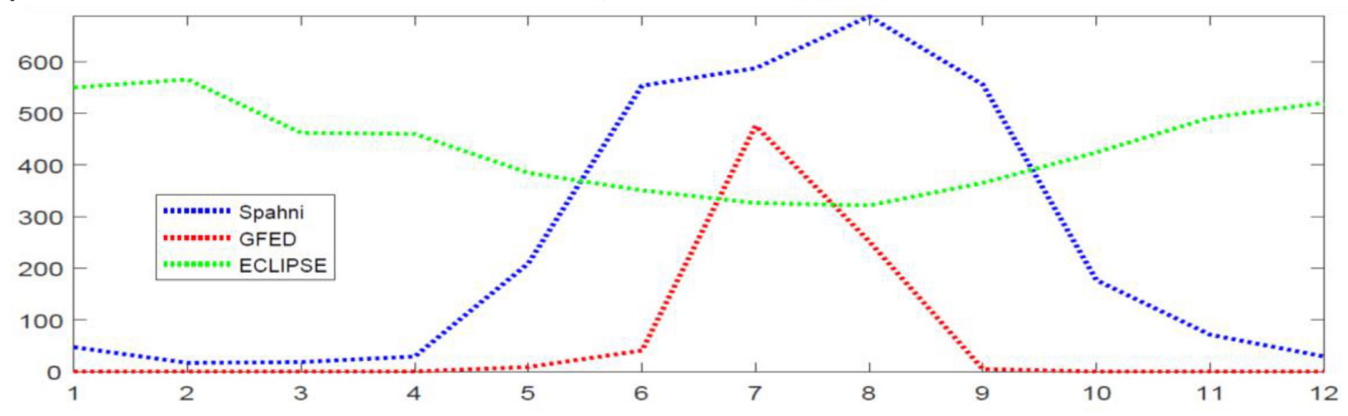

Figure 4. (a) Annual average high-latitude $\mathrm{CH}_{4}$ emissions from anthropogenic sources, wetlands, and biomass burning according to GAINS ECLIPSE (Stohl et al., 2015; http://www.iiasa.ac.at/web/home/research/researchPrograms/air/ECLIPSEv5a.html, last access: 21 November 2018), LPX-Bern (Spahni et al., 2011; Stocker et al., 2014; http://www.climate.unibe.ch/), and the Global Fire Emissions Database, GFED (Randerson et al., 2017), respectively. (b) Monthly variation in anthropogenic, wetland, and biomass burning emissions above $60^{\circ} \mathrm{N}$.

and leak rates may be as high as $10 \%$ (Hayhoe et al., 2002; Thompson et al., 2017). Furthermore, according to the GAINS-ECLIPSE model, fuel production and distribution represented the largest fraction, $\sim 87 \%$, of $\mathrm{CH}_{4}$ emissions from Asian Russia. These emissions are expected to steadily increase from an estimated $12900-14400 \mathrm{ktCH}_{4} \mathrm{yr}^{-1}$ between 2010 and 2030, still markedly down from an estimated $19600 \mathrm{ktCH}_{4} \mathrm{yr}^{-1}$ in 1990 . Some areas of western Europe, e.g. the UK and the Netherlands, are also expected to influence high-latitude $\mathrm{CH}_{4}$ mixing ratios. Western European $\mathrm{CH}_{4}$ emissions are from waste treatment and agriculture and are expected to steadily decrease. Meanwhile, for wetland emissions, the source regions are much more widely distributed, covering in particular large areas of Siberia, north-western Russia, Fennoscandia, western Europe, and North America. Finally, biomass burning events tend to occur in heavily forested regions of eastern Siberia and Canada (Fig. 4a). Wetland emissions are expected to dominate from June to September above $60^{\circ} \mathrm{N}$, with anthropogenic emissions dominant for the rest of the year (Fig. 4b).

\subsection{Methane at the RV Helmer Hanssen}

Methane mixing ratios measured at the RV Helmer Hanssen tended to be elevated close to the Norwegian coast and around Kongsfjorden $\left(78.75^{\circ} \mathrm{N}, 16^{\circ} \mathrm{E}\right.$, Svalbard, Fig. 5), explained by higher sensitivity to terrestrial emissions, since there are numerous settlements and fossil fuel industry installations along the Norwegian coast and in the Kongsfjorden area. Repeated instances of high $\mathrm{CH}_{4}$ in the Barents Sea also apparent in Fig. 5 coincide with increased sensitivity to emissions from land-based sources according to FLEXPART, likely because this area is relatively close to major emissions sources.

We observed a clear link between $\mathrm{CO}_{2}$ mixing ratios and $\mathrm{CH}_{4}$ (Fig. 6, Fig. S2). In winter, $\mathrm{CH}_{4}$ tends to increase together with $\mathrm{CO}_{2}$, indicative of $\mathrm{CH}_{4}$ produced via combustion processes, i.e. mainly from anthropogenic sources (Fig. S2). In summer, many observed $\mathrm{CH}_{4}$ excursions coincide with decreased $\mathrm{CO}_{2}$, typical for $\mathrm{CH}_{4}$ from biologically active regions where photosynthesis depletes $\mathrm{CO}_{2}$. These observations thus validate the predictions of the model and emission inventories whereby we expect anthropogenic emissions to 

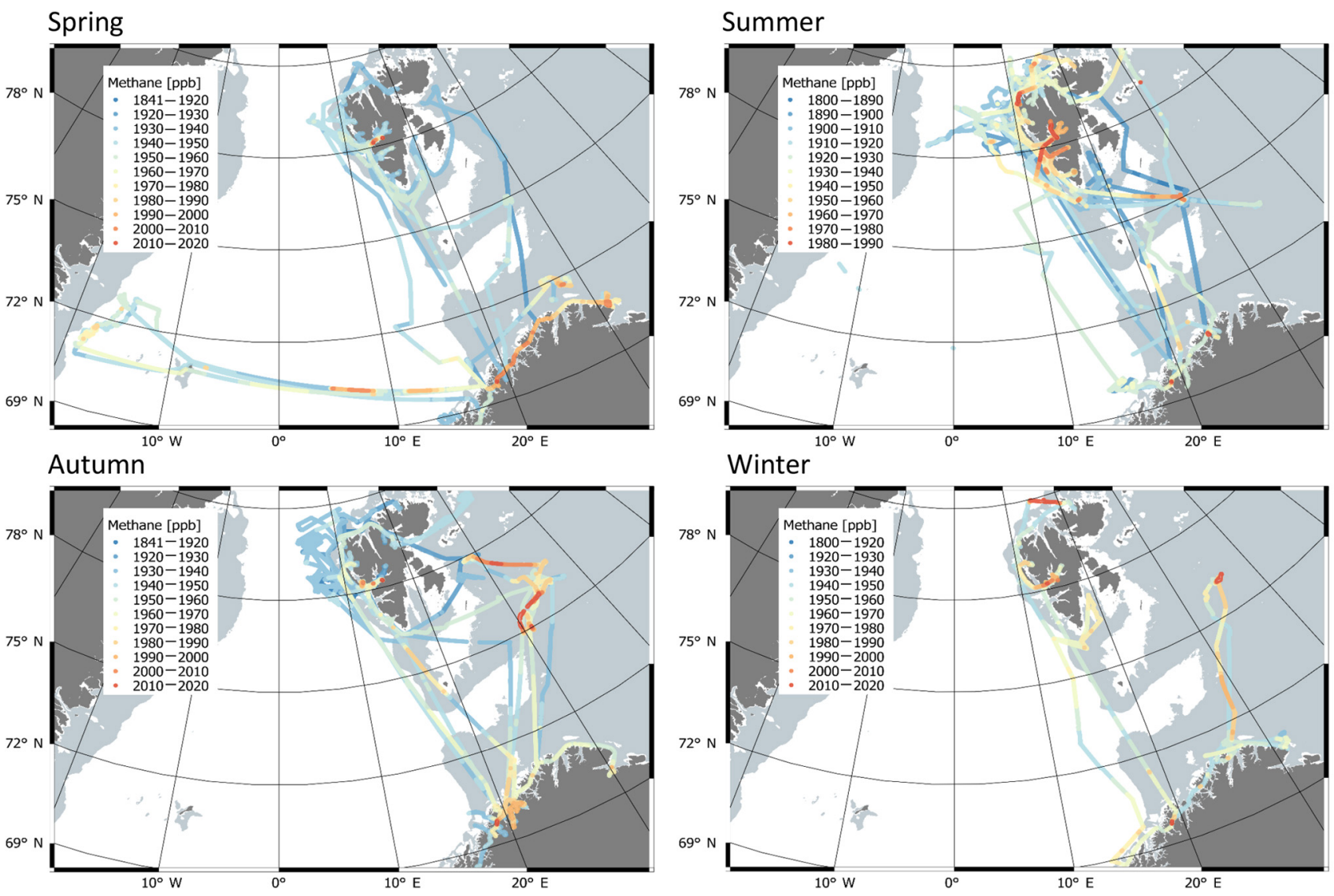

Figure 5. Methane mixing ratios observed at the RV Helmer Hanssen (colour scale), by location and plotted by calendar season (i.e. winter is December/January/February). Please note the change in colour scale between panels.

be the largest contributor to winter variability in $\mathrm{CH}_{4}$ mixing ratios and wetlands the largest contributor in summer (Fig. S2). We observe only one occurrence of a large $\mathrm{CH}_{4}$ excursion (>10 ppb) throughout the entire measurement series on 25 August 2014 without a corresponding perturbation of the Zeppelin Observatory $\mathrm{CH}_{4}$, RV Helmer Hanssen $\mathrm{CO}_{2}$, or FLEXPART emissions time series (Fig. 6, Fig. S2).

We assess the agreement between the Zeppelin Observatory and modelled emissions and the RV Helmer Hanssen $\mathrm{CH}_{4}$ time series on a monthly basis in the Taylor diagrams (Taylor, 2001) in Fig. 7, which shows the $R^{2}$ correlation on the angular axis and the ratio of standard deviations (Zeppelin to the RV Helmer Hanssen) on the radial axis. Monthly correlations range from 0.1 to 0.8 for both the modelled emissions and the Zeppelin Observatory, while for most months the standard deviation of the Zeppelin $\mathrm{CH}_{4}$ is below that of the RV Helmer Hanssen, likely reflecting the fact that the latter is exposed to more variable sources as a moving platform at sea level. The agreement between the model and observations is mostly above $R^{2}=0.3$, as Thompson et al. (2017) also report for a number of high-latitude measurement sta- tions. For some months, the correlation between the model and observations is strikingly high, e.g. March 2015/2016.

\subsection{Ocean-atmosphere emissions north of Svalbard}

The aforementioned unexplained episode of increased $\mathrm{CH}_{4}$ on $\sim 25$ August 2014 (Fig. 6 ) occurred at $80.4^{\circ} \mathrm{N}, 12.8^{\circ} \mathrm{E}$, north of Svalbard. During this North Svalbard episode (NSE) wind speeds were $\sim 7 \mathrm{~m} \mathrm{~s}^{-1}$ from a northerly direction. The absence of an excursion in the $\mathrm{CO}_{2}$ mixing ratio at the same time suggests limited influence of wetlands (where a decrease would be expected) or anthropogenic emissions (where an increase would be expected). It is also noteworthy that the NSE is not predicted by the FLEXPART emissions, even though every other excursion $>10 \mathrm{ppb}$ during the entire measurement time series is predicted (Fig. S3). The FLEXPART footprint sensitivity shown in Figs. 8 and 9 for the RV Helmer Hanssen suggests that the measurements were highly sensitive to emissions close to the ship's location and over ocean areas north of Svalbard. Mixing ratios decreased as the measurements became less sensitive to this area after 12:00 on 26 August 2014 and then increased signif- 


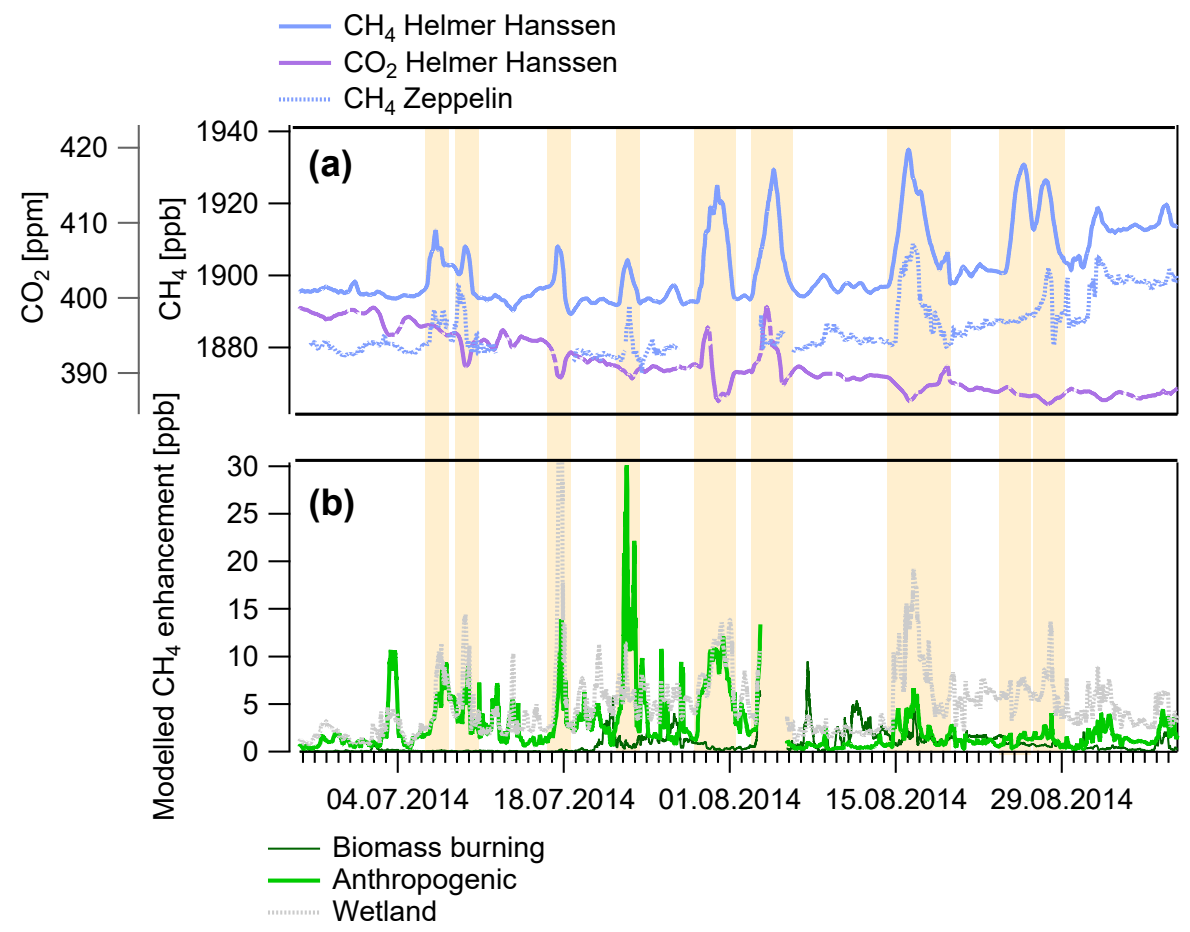

Figure 6. Example time series and model data presented in this study, from summer 2014 data. (a) shows observation data of high time resolution $(1 \mathrm{~h})$ methane $\left(\mathrm{CH}_{4}\right.$, light blue), carbon dioxide $\left(\mathrm{CO}_{2}\right.$, purple dashed) at the $\mathrm{RV}$ Helmer Hanssen, and $\mathrm{CH}_{4}$ at Zeppelin for ship positions within $75-82^{\circ} \mathrm{N}, 5-35^{\circ} \mathrm{E}$ (blue dotted). (b) shows the modelled $\mathrm{CH}_{4}$ enhancement due to anthropogenic activity (green), wetlands (grey), and biomass burning (dark green) according to emission inventories and FLEXPART (see text for details). Major excursions in the $\mathrm{RV}$ Helmer Hanssen $\mathrm{CH}_{4}$ mixing ratio are highlighted.
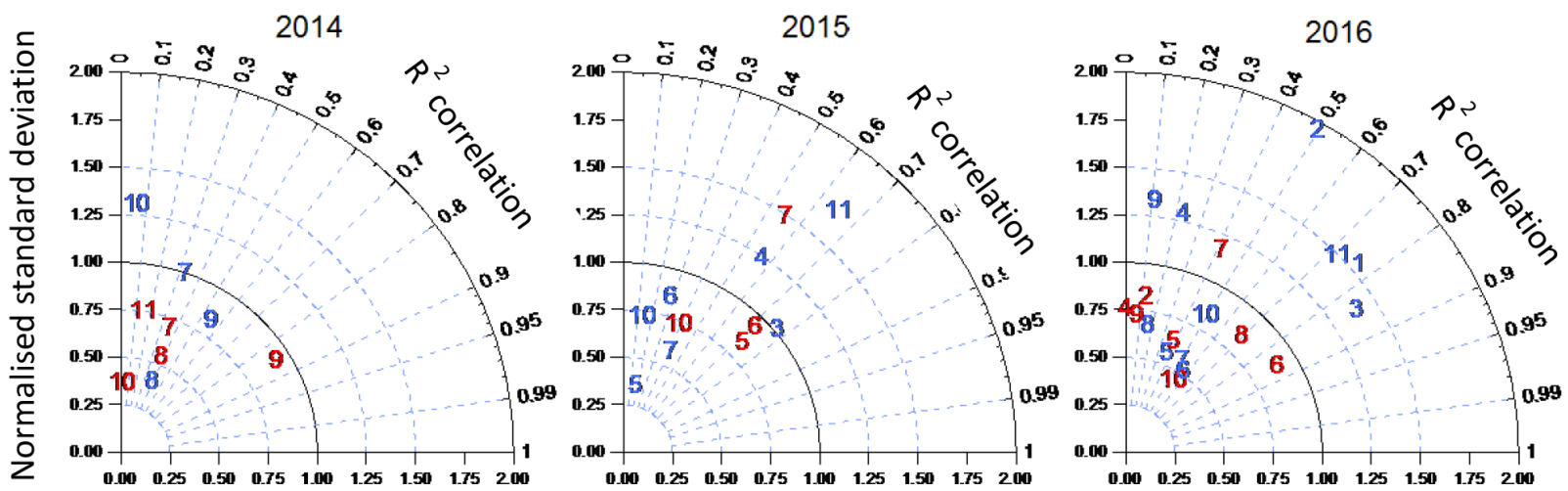

FLEXPART Emission vs. Helmer Hanssen

Zeppelin vs. Helmer Hanssen

Figure 7. Taylor diagrams showing the monthly $R^{2}$ correlation (angle) and normalized standard deviation (radial axis) of modelled $\mathrm{CH}_{4}$ emissions (blue) and $\mathrm{CH}_{4}$ observed at Zeppelin Observatory (red, only for ship positions within $75-82^{\circ} \mathrm{N}, 5-35^{\circ}$ ) compared to the $\mathrm{RV}$ Helmer Hanssen $\mathrm{CH}_{4}$ time series. Numbers refer to month of the year. Ideal agreement would be found at 1 on the radial axis (black line) and 1 on the angular axis.

icantly once more on 27 August 2014 where measurements are likely to be influenced by wetland emissions in northeastern Russia, as also predicted by FLEXPART. During the
NSE the Zeppelin Observatory was also highly sensitive to an area close to the measurement site, in this case however slightly to the south, mainly over land (north-western Sval- 


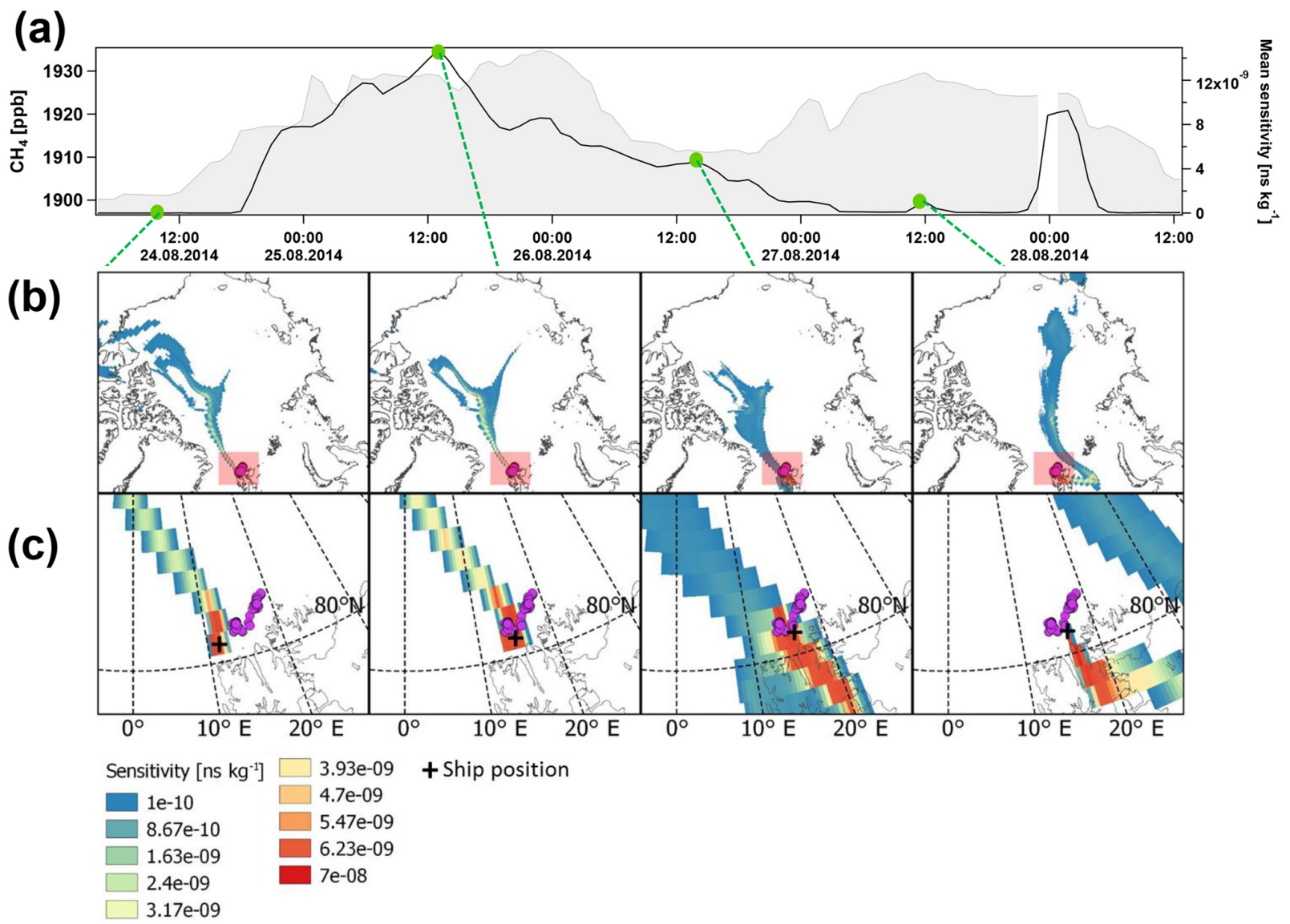

Figure 8. (a) Methane $\left(\mathrm{CH}_{4}\right)$ measured north of Svalbard at the RV Helmer Hanssen shortly before, during, and after an episode of increased mixing ratios (grey shaded area) and mean footprint sensitivity (black line) to active flares located at $80.39-81.11^{\circ} \mathrm{N}, 13.83-19^{\circ} \mathrm{E}$, according to Geissler et al. (2016), (b) regional FLEXPART footprint sensitivities in $\mathrm{ns} \mathrm{kg}^{-1}$, colour scale, and (c) local footprint FLEXPART sensitivities, for the area given by the red overview in (b), including the locations of seabed gas flares, from Geissler et al. (2016).

bard), while the sensitivity to land areas outside Svalbard appears similar (and very low) for both (Fig. S3).

During the NSE, measurements were sensitive to the relatively shallow Svalbard continental margin including the Hinlopen Strait $\left(79.62^{\circ} \mathrm{N}, 18.78^{\circ} \mathrm{E}\right)$ and Norskebanken $\left(81.00^{\circ} \mathrm{N}, 14.00^{\circ} \mathrm{E}\right)$ and Yermak plateaux $\left(81.25^{\circ} \mathrm{N}\right.$, $5.00^{\circ} \mathrm{E}$ ), (Fig. 8). This area is the site of the HinlopenYermak Megaslide 30000 years before present (Winkelmann et al., 2006), where numerous bubble plumes (referred to as flares) emanating from the sea floor were recently discovered using echo-sounding and attributed to $\mathrm{CH}_{4}$ venting (Geissler et al., 2016). We conclude that elevated mixing ratios on 25 August 2014 were the result of an oceanatmosphere flux, based on the thorough analysis of over 2 years of measurement and model data, the presence of methane seepage, wind analysis, and the footprint sensitivities shown in Figs. 8 and 9.

As described previously, the footprint sensitivity and the flux density of emissions within the sensitivity field yield the mixing ratio change at a receptor. We define the area of interest according to the active flare region described by Geissler et al. (2016) (Fig. 8c). There is a clear agreement between mean sensitivity to this active flare region and the atmospheric $\mathrm{CH}_{4}$ mixing ratio observed at the Helmer Hanssen (Fig. 9). Therefore, we calculate a flux for this area during this period (23-27 August 2014) by normalizing the change in mixing ratio to the change in mean footprint sensitivity. The measurement points of the lowest and highest $\mathrm{CH}_{4}$ mixing ratios are well defined by the 25th and 75th percentiles, respectively (Fig. 9). To provide an estimate of the uncertainty in the flux we use a simple bootstrap: we generated new time series for $\mathrm{CH}_{4}$ and mean sensitivity to the area of interest by resampling pairs of data points from the originals at random to create new time series of identical length and performed multiple repeats $(n=10000)$ of the flux calculation. Accordingly, we attain a flux of $25.77 \pm 1.75 \mathrm{nmol} \mathrm{m}^{-2} \mathrm{~s}^{-1}$, a total of $0.73 \pm 0.05 \mathrm{Gg} \mathrm{yr}^{-1}$ (assuming the flux only occurs in summer when the area is icefree). We show the bootstrap distribution in Fig. S4. 


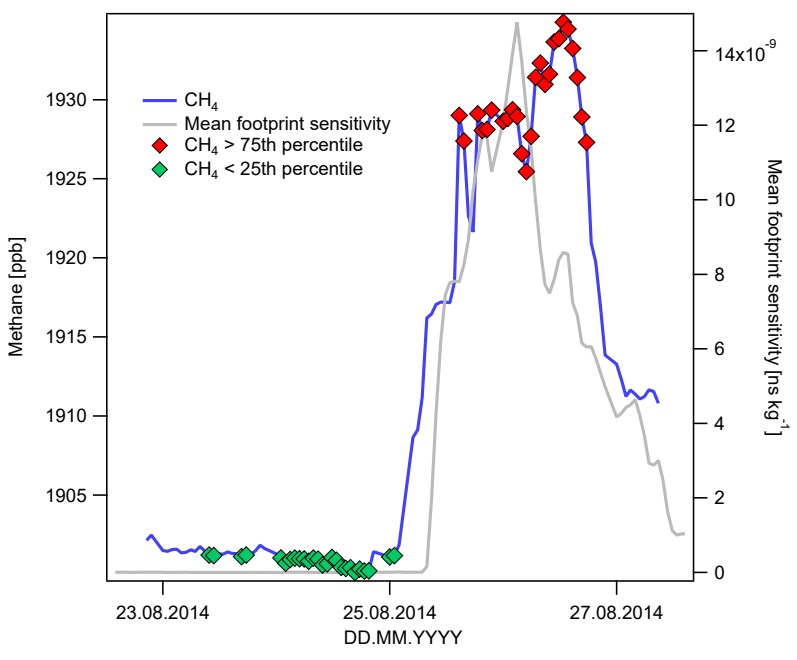

Figure 9. The methane $\left(\mathrm{CH}_{4}\right)$ atmospheric mixing ratio observed at the Helmer Hanssen north of Svalbard and mean footprint sensitivity to the active sub-sea seep region described by Geissler et al. (2016), from $80.39-81.11^{\circ} \mathrm{N}, 13.83-19^{\circ} \mathrm{E}$ (see also Fig. 8c), total area $3582.43 \mathrm{~km}^{2}$. Points used to estimate a flux, i.e. the highest $\mathrm{CH}_{4}$ mixing ratios (above the 75th percentile) are shown in red and points corresponding to the lowest $\mathrm{CH}_{4}$ mixing ratios (below the 25 th percentile) are shown in green. Mean sensitivity to this area was determined using bilinear interpolation of the original $0.5^{\circ} \times 0.5^{\circ}$ FLEXPART footprint sensitivity field.

There are two possible scenarios to explain why the NSE only appears to influence the RV Helmer Hanssen $\mathrm{CH}_{4}$ time series on only one occasion: (1) a relatively high transient flux and (2) a transient, relatively high sensitivity to a small flux occurring in the area of interest. In order to evaluate this we repeat the calculation described above for all summertime periods (the area is largely ice bound outside of summer periods); i.e. we constrain the flux based on the difference in mixing ratios during time periods least sensitive and most sensitive to the area of interest, "upwind" and "downwind", respectively. For such a case, the estimate yields the maximum emission consistent with observations since it also neglects the influence of emissions outside the region of interest, while the true flux may be significantly lower or even negative. Pisso et al. (2016) describe and evaluate this upwind-downwind methodology for constraining fluxes in more detail. We attained a maximum flux of $18.24 \pm 2.79 \mathrm{nmol} \mathrm{m}^{-2} \mathrm{~s}^{-1}$ based on all summer data, with the upwind-downwind analysis, slightly lower than the flux calculated for the NSE. This suggests that there was at least some increase in the $\mathrm{CH}_{4}$ flux during the NSE relative to most periods (since the upwind-downwind calculation yields an absolute maximum). However, this difference is rather small, and Pisso et al. (2016) estimated a very similar flux threshold of $21.50 \mathrm{nmol} \mathrm{m}^{-2} \mathrm{~s}^{-1}$ from an area around Svalbard covering $1644 \mathrm{~km}^{2}$ where gas seeps have been observed. Accordingly, the area of interest north of Svalbard is unlikely to be unique in the context of the wider Arctic. Rather, the meteorology at the time of the observation was unique in the context of the measurement time series; i.e. we obtained, over the short course of the episode, measurements highly sensitive to emissions over an active seep site, without sensitivity to land-based emissions.

Extrapolating the flux densities in Table 1 to the known seep area, we attain a flux of up to $0.021 \pm 0.001 \mathrm{Tg} \mathrm{yr}^{-1}$. This is obviously small compared to a global $\mathrm{CH}_{4}$ budget of $550 \mathrm{Tg} \mathrm{yr}^{-1}$ (Saunois et al., 2016). Furthermore, only a change over time in the magnitude of a source will result in a climate forcing, suggesting only a very small influence of seafloor methane venting from this region on climate change at present.

The ocean depth at the North Svalbard location was $~$ $500 \mathrm{~m}$. From this depth, it is very likely that $\mathrm{CH}_{4}$ bubbles emanating from the sea floor will contain a gas phase composition almost identical to that of the atmosphere by the time they reach the surface due to diffusive exchange with dissolved gases in the water column. Any $\mathrm{CH}_{4}$ flux from the ocean is therefore likely to be via diffusive flux of dissolved methane to the atmosphere. Since the ocean-atmosphere flux $(F)$ is known it is also possible to estimate surface water concentrations $\left(C_{\mathrm{w}}\right)$ at the time of the episode by rearranging the sea-air exchange parameterization of Wanninkhof et al. (2009), i.e.:

$F=k\left(C_{\mathrm{w}}-C_{0,}\right) \rightarrow C_{\mathrm{w}}=\frac{F}{k}+C_{0}$,

where $k$ is the gas transfer velocity and $C_{0}$ is the equilibrium dissolved $\mathrm{CH}_{4}$ concentration at the surface. $C_{0}$ is given by

$$
\begin{aligned}
C_{0}= & \exp \left\{P_{\mathrm{CH}_{4}}-415.2807+596.8104\left(\frac{100}{T_{\mathrm{w}}}\right)\right. \\
& +379.2599\left[\ln \left(\frac{T_{\mathrm{w}}}{100}\right)\right]-62.0757\left(\frac{T_{\mathrm{w}}}{100}\right) \\
& +S\left(-0.059160+0.032174\left(\frac{T_{\mathrm{w}}}{100}\right)\right. \\
& \left.\left.-0.0048198\left(\frac{T_{\mathrm{w}}}{100}\right)^{2}\right)\right\},
\end{aligned}
$$

where $P_{\mathrm{CH}_{4}}$ is the partial pressure of methane in the atmosphere, $S$ is the salinity of spray above the ocean surface in $\%$, which we assume is equivalent to surface water salinity, and $T_{\mathrm{w}}$ is the water temperature in Kelvins, from Wiesenburg and Guinasso Jr. (1979). Equation (2) is valid for moist air, while we measure the dry air $\mathrm{CH}_{4}$ mixing ratio $\left(X_{\mathrm{CH}_{4} \text {, dry }}\right)$. To calculate $P_{\mathrm{CH}_{4}}$ in the presence of water vapour we use

$P_{\mathrm{CH}_{4}}=X_{\mathrm{CH}_{4}, \text { dry }} \times P_{\text {atm }}\left(1-P_{\mathrm{H}_{2} \mathrm{O}}\right)$,

where $P_{\text {atm }}$ is the measured atmospheric pressure and $P_{\mathrm{H}_{2} \mathrm{O}}$ is the partial pressure of water, calculated according to Buck (1981) and accounting for measured relative humidity, 
Table 1. Maximum fluxes of methane from the ocean at the North Svalbard location determined from summer data and the flux during the episode of high $\mathrm{CH}_{4}$ mixing ratios.

\begin{tabular}{lccc}
\hline Summertime (maximum from constraint) & \multicolumn{2}{c}{ Flux during episode } \\
\hline $\begin{array}{l}\text { Flux density } \\
\left(\mathrm{nmol} \mathrm{m}^{-2} \mathrm{~s}^{-1}\right)\end{array}$ & $\begin{array}{c}\text { Total emission } \\
\left(\mathrm{Gg} \mathrm{yr}^{-1}\right)\end{array}$ & $\begin{array}{c}\text { Flux density } \\
\left(\mathrm{nmol} \mathrm{m}^{-2} \mathrm{~s}^{-1}\right)\end{array}$ & $\begin{array}{c}\text { Total emission } \\
\left(\mathrm{Gg} \mathrm{yr}^{-1}\right)\end{array}$ \\
\hline $18.24 \pm 2.79$ & $0.52 \pm 0.08$ & $25.77 \pm 1.75$ & $0.73 \pm 0.05$ \\
\hline
\end{tabular}

RH\%:

$$
\begin{aligned}
P_{\mathrm{H}_{2} \mathrm{O}}= & 0.61121 \cdot \exp \left\{18.678-\left(\frac{T_{\text {air }}}{234.5}\right)\right. \\
& \left.\left(\frac{T_{\text {air }}}{257.14+T_{\text {air }}}\right)\right\} \cdot \frac{\mathrm{RH} \%}{100},
\end{aligned}
$$

where $T_{\text {air }}$ is the measured air temperature in ${ }^{\circ} \mathrm{C}$. The gas transfer velocity in Eq. (2) is given by

$k=0.24 \times u_{10}^{2}\left(\frac{S c}{660}\right)^{-0.5}$

where $u_{10}$ is the wind velocity at $10 \mathrm{~m}$ and $S c$ is the Schmidt number, the non-dimensional ratio of gas diffusivity and water kinematic viscosity. We calculate $S c$ using the parameterization of Wanninkhof (2014):

$$
\begin{aligned}
S c= & 2101.2-\left(131.54\left(T_{\mathrm{w}}-273.15\right)\right) \\
& +\left(4.4931\left(T_{\mathrm{w}}-273.15\right)\right)^{2} \\
& -\left(0.08676\left(T_{\mathrm{w}}-273.15\right)\right)^{3} \\
& +\left(0.00070663 \times\left(T_{\mathrm{w}}-273.15\right)\right)^{4} .
\end{aligned}
$$

Finally, we correct for the difference in measurement height (22.4 $\mathrm{m}$ ) and $u_{10}$ using a power-law dependence described by

$u_{10}=u_{22.4} \times\left(\frac{10}{22.4}\right)^{0.11}$

Equation (6) shows that $\mathrm{CH}_{4}$ flux is proportional to the square of wind speed, while Eq. (7) demonstrates that water temperature also has a non-linear effect on the flux via the Schmidt number. Wind speed and water temperature are thus the two most important factors determining the ocean-atmosphere methane flux. We calculate uncertainties in Eq. (2) via a Monte Carlo approach by performing 10000 repeat calculations and incorporating normally distributed random noise (mean values of zero, standard deviations from observations) for wind speed, $\mathrm{CH}_{4}$ atmospheric mixing ratios, and water temperatures. We use the bootstrap distribution in Fig. S4 for the uncertainty of the flux. We then calculate the final uncertainty in $C_{\mathrm{w}}$ from the distribution of the results from the Monte Carlo simulation.

During the NSE, we calculate that a dissolved $\mathrm{CH}_{4}$ concentration of $555 \pm 297 \mathrm{nmol} \mathrm{L}^{-1}$ would have been required to generate the transient flux of $25.77 \pm 1.75 \mathrm{nmol} \mathrm{m}^{-2} \mathrm{~s}^{-1}$ given in Table 1. This concentration is higher than what was observed in surface waters over shallow (50-120 m depth) seep sites west of Svalbard where Graves et al. (2015) report surface water $\mathrm{CH}_{4}$ concentrations $<52 \mathrm{nmol} \mathrm{L}^{-1}$. Very high fluxes of $\mathrm{CH}_{4}$ from sub-seabed sources to the atmosphere have also been reported for the East Siberian Arctic Shelf (ESAS) (Shakhova et al., 2014), with flux values of $\sim 70$ $450 \mathrm{nmol} \mathrm{m}^{-2} \mathrm{~s}^{-1}$ under stormy conditions with surface water concentrations of the order of $450 \mathrm{nmol} \mathrm{L}^{-1}$. However, the emissions reported for ESAS were over shallow water, and bubble dissolution, gas exchange, water column stratification, and microbial oxidation would significantly diminish $\mathrm{CH}_{4}$ concentrations in the surface mixed layer above bubble emission sites in water depth $>100 \mathrm{~m}$ (McGinnis et al., 2006; Graves et al., 2015; Mau et al., 2017). Thus, there is an offset between the observed dissolved $\mathrm{CH}_{4}$ concentrations and those previously observed over active marine seeps. Possible explanations for this offset include (1) errors in the estimate of dissolved water $\mathrm{CH}_{4}$ concentrations; (2) additional (i.e. not seep-related) sources of $\mathrm{CH}_{4}$ in the water column; (3) water conditions unique to this location and time allowing for higher dissolved $\mathrm{CH}_{4}$ concentrations than normal in the region; and (4) that the atmospheric $\mathrm{CH}_{4}$ is at least partly from another source.

All of the above scenarios are possible to varying degrees. The Wanninkhof parameterization (Eqs. 2-8) assumes emissions over a flat surface, which would be violated in the case of wind speeds at the time of the NSE of up to $7 \mathrm{~m} \mathrm{~s}^{-1}$. Another source of error in the $\mathrm{Cw}$ estimation might be differences in wind speed over the seep site and measured at the RV Helmer Hanssen. Furthermore, while uncertainties in the required $\mathrm{C}_{W}$ are large, it should be noted that extreme values of dissolved $\mathrm{CH}_{4}$ (e.g. $>10^{9} \mathrm{nmol} \mathrm{L}^{-1}$ ) are obtainable from Eq. (2) for a net positive flux as wind speeds (and hence gas transfer velocity) approach zero. This nonlinear effect of wind speed is also evident in Fig. S5 which shows that the dissolved $\mathrm{CH}_{4}$ required to produce the estimated oceanatmosphere flux increases rapidly as the wind speed drops from $7 \mathrm{~m} \mathrm{~s}^{-1}$ to close to $1 \mathrm{~m} \mathrm{~s}^{-1}$. I.e. the offset between previously observed dissolved $\mathrm{CH}_{4}$ concentrations is small compared to what is obtainable via Eq. (2).

Other sources of marine $\mathrm{CH}_{4}$ are also possible since the area had been covered by close drift ice only 1 week prior to our observations, and some open drift ice was still present 
Table 2. Gas composition of hydrate and gravity core samples by mass from the Storfjordrenna hydrate pingo area according to this work and Serov et al. (2017).

\begin{tabular}{lrrrr}
\hline & CAGE 15-2 HH 911 GC $\left(15.97^{\circ} \mathrm{E}, 76.11^{\circ} \mathrm{N}\right)$ & \multicolumn{2}{c}{ CAGE 15-2 HH 914 GC $\left(16.03^{\circ} \mathrm{E}, 76.11^{\circ} \mathrm{N}\right)$} \\
\hline & This work & Serov et al. $(2017)$ & This work & Serov et al. (2017) \\
\hline $\mathrm{C}_{1} /\left(\mathrm{C}_{2}+\mathrm{C}_{3}\right)$ & 2379.95 & $164.51 \pm 173.27$ & 853.70 & $121.70 \pm 90.42$ \\
$\delta^{13} \mathrm{C} \mathrm{V-PDB}$ & $-45.34 \pm 0.03$ & -48.4 & $-45.65 \pm 0.04$ & -44.7 \\
\hline
\end{tabular}

in the area at the time of the measurements (Fig. S6). If any $\mathrm{CH}_{4}$ is trapped under ice during winter, it may suddenly be released when the ice melts or is blown away. For example, Kort et al. (2012) report similar ocean-atmosphere $\mathrm{CH}_{4}$ fluxes to those in this work of up to $2 \mathrm{mg} \mathrm{d}^{-1} \mathrm{~m}^{-2}$ $\left(23 \mathrm{nmol} \mathrm{m}^{-2} \mathrm{~s}^{-1}\right)$ from observations of atmospheric $\mathrm{CH}_{4}$ at Arctic sea-ice margins and ice leads. Meanwhile, Thornton et al. (2016) estimate that relatively high short-lived $\mathrm{CH}_{4}$ fluxes from the East Siberian Sea occur around melting ice, at $11.9 \mathrm{nmol} \mathrm{m}^{-2} \mathrm{~s}^{-1}$ (ice melt) vs. $2.7 \mathrm{nmol} \mathrm{m}^{-2} \mathrm{~s}^{-1}$ (icefree).

A higher dissolved $\mathrm{CH}_{4}$ concentration than observed west of Svalbard might also be due to rather low water temperatures at the North Svalbard site. We measured a water temperature of $0.7^{\circ} \mathrm{C}$ for the area vs. $2-5^{\circ} \mathrm{C}$ for shallow waters west of Svalbard, which might result in reduced $\mathrm{CH}_{4}$ oxidation rates by methanotrophic bacteria, generally the main factor controlling $\mathrm{CH}_{4}$ concentrations in the water column (Graves et al., 2015). Furthermore, lateral transport of $\mathrm{CH}_{4}$ by ocean currents is also an important factor controlling dissolved concentrations and can be expected to vary by location (Steinle et al., 2015).

Finally, we cannot rule out other sources of $\mathrm{CH}_{4}$ to the atmosphere, since these might be responsible for the observed excursion. This might be because of error in the footprint sensitivity field and/or an extremely large flux in areas of low sensitivity. In summary therefore, there is no way to definitively prove with available information that the NSE is due to ocean emissions, even if the evidence in favour of this is strong. Note that if there is no flux from the ocean, then the values in Table 1 can be considered a constraint (maximum flux consistent with observations) on the $\mathrm{CH}_{4}$ oceanatmosphere flux at this location.

\subsection{Offline trace gases and their potential use as gas hydrate tracers}

While we present evidence of an observed ocean-atmosphere $\mathrm{CH}_{4}$ flux in the previous section, the task of identifying and quantifying such fluxes would be considerably simplified if a unique tracer for oceanic $\mathrm{CH}_{4}$ emissions were to exist. For this reason, we developed the new technique to analyse $\mathrm{GH}$ composition described previously. On 23 May 2015 we took two sediment cores, CAGE 15-2 HH 911 GC and CAGE 15$2 \mathrm{HH} 914 \mathrm{GC}$, from the seafloor at $76.11^{\circ} \mathrm{N}, 15.97^{\circ} \mathrm{E}$ and $76.11^{\circ} \mathrm{N}, 16.03^{\circ} \mathrm{E}$, respectively (Fig.1 and Table 2). This area is noteworthy for the presence of conical hills or mounds (Serov et al., 2017) similar to terrestrial features called "pingos" (Mackay, 1998), with heights of $\sim 10-40$ and $100 \mathrm{~m}$ in diameter, and rising up to as near as $18 \mathrm{~m}$ to the sea surface. The core extracted at this location contained visible $\mathrm{GH}$ deposits, which we immediately sampled into an evacuated stainless steel flask for offline analysis of isotopes and trace gases.

The two GH samples contained $0.042 \%$ and $0.117 \%$ ethane by mass (average $0.080 \%$ ), with the remaining volume consisting of methane (Table 2). All other hydrocarbons tested for (e.g. propane, butane) were below the detection limit, i.e. below ppt level (Miller et al., 2008), strong evidence of sample purity, since contamination with atmospheric air would lead to the presence of numerous other trace gases. We also determined isotopic ratios of $-45.34 \%$ o $0.03 \%$ and $-45.65 \%$ $\pm 0.04 \%$ o $\delta^{13} \mathrm{C}$ in $\mathrm{CH}_{4}$ vs. V-PDB. The composition of gas contained in the same sediment cores as estimated by Serov et al. (2017) using the glass vial/headspace method described in Sect. 2.4 is compared to our method in Table 2. For sample CAGE 15-2 HH $911 \mathrm{GC}$, Serov et al. (2017) report an average methane/light hydrocarbon (ethane and propane) ratio $\left(\mathrm{C}_{1} /\left(\mathrm{C}_{2}+\mathrm{C}_{3}\right)\right)$ an order of magnitude lower than observed using our methodology. Although the standard deviation was high, the maximum observed $\mathrm{C}_{1} /\left(\mathrm{C}_{2}+\mathrm{C}_{3}\right)$ value was 460.06 vs. our value, 2379.95. For sample CAGE 15-2 HH 914 GC, we observe a similar result: $\mathrm{C}_{1} /\left(\mathrm{C}_{2}+\mathrm{C}_{3}\right)$ is higher using our methodology (1256.39) vs. the headspace method $(121.7 \pm 90.52$, maximum 239.38). There may be several reasons for these discrepancies, as outlined in Sect. 2.4.

The relationship between hydrocarbon composition and isotopic composition can be used to define whether natural gas from a hydrocarbon seep is of thermogenic (cracking of hydrocarbons below the Earth's surface) or of biogenic origin (Bernard et al., 1976; Smith et al., 2014; Faramawy et al., 2016). Thermogenic natural gas exhibits $C_{1} /\left(C_{2}+C_{3}\right)$ $<1000$ and $\delta^{13} \mathrm{C}$ in $\mathrm{CH}_{4} \mathrm{~V}-\mathrm{PDB}>-50 \%$, whereas biogenic gas exhibits $\mathrm{C}_{1} /\left(\mathrm{C}_{2}+\mathrm{C}_{3}\right)>200$ and $\delta^{13} \mathrm{C}$ in $\mathrm{CH}_{4}$ V-PDB $<-50 \%$. Samples between these ranges are of mixed origin. Thus, based on the values shown in Table 2 (and other core samples around the same location), Serov et al. (2017) identify the gas contained in the sediments as unambiguously thermogenic in origin. However, the gas composition 
of the hydrates within the gravity cores determined using our methodology points to a biogenic or more mixed origin, since the $\mathrm{C}_{2}+\mathrm{C}_{3}$ fraction is rather low. Furthermore, hydrates are typically enriched in $\mathrm{C} 2$ and $\mathrm{C} 3$ hydrocarbons compared to the seep gas from which they emanate due to molecular fractionation (Sloan Jr., 1998), suggesting a lower $\mathrm{C}_{2}+\mathrm{C}_{3}$ fraction, and a lower thermogenic gas contribution in the sediments, than reported by Serov et al. (2017). Our results therefore demonstrate, at the very least, the need for a harmonized technique for the analysis of natural gas from sediments, since the different methodologies used here indicate different sediment histories.

The $\mathrm{C}_{1} /\left(\mathrm{C}_{2}+\mathrm{C}_{3}\right)$ ratios for the hydrate samples are close to those of the ambient atmosphere in the Arctic. For air samples collected in summer 2014, summer 2015, and autumn 2015 we obtain $\mathrm{C}_{1} /\left(\mathrm{C}_{2}+\mathrm{C}_{3}\right)$ ratios of $2119.4,2131.31$, and 1467.21, respectively. The range over all values was from a minimum of 1230.39 to a maximum of 2526.17. We observed higher ratios in winter when photochemistry is slower and there is less oxidation of the relatively short-lived ethane/propane compared to $\mathrm{CH}_{4}$. We therefore expect ratios lower than 2526.31 in winter.

The background variations in $\mathrm{C}_{1} /\left(\mathrm{C}_{2}+\mathrm{C}_{3}\right)$ ratios show that ethane is not a unique tracer for emissions to the atmosphere from hydrates of biogenic or mixed origin, i.e. additional information is required to quantify hydrate methane emission to the atmosphere. For example, using the summer 2014 data, a large enhancement in the $\mathrm{CH}_{4}$ mixing ratio due to hydrate emissions reaching the atmosphere of $100 \mathrm{ppb}$ would perturb the atmospheric $\mathrm{C}_{1} /\left(\mathrm{C}_{2}+\mathrm{C}_{3}\right)$ ratio from 2131.31 to 2007.54 , which would be detectable, but is well within the normal variation of the background ambient levels. Thermogenic hydrate emissions to the atmosphere meanwhile would produce larger variations. Using a $\mathrm{C}_{1} /\left(\mathrm{C}_{2}+\mathrm{C}_{3}\right)$ ratio for gas hydrates of 121.7 from Table 2 , we attain a change in atmospheric $\mathrm{C}_{1} /\left(\mathrm{C}_{2}+\mathrm{C}_{3}\right)$ ratio from 2131.31 to 1109.93 for a 100 ppb increase in $\mathrm{CH}_{4}$ mixing ratio due to gas hydrates, just outside the range of observed ambient values in this study. Thus the $C_{1} /\left(C_{2}+C_{3}\right)$ ratio might be useful to identify $\mathrm{CH}_{4}$ reaching the atmosphere from thermogenic seeps and hydrates, however this would only be applicable in extreme cases, since we did not observe excursions from the $\mathrm{CH}_{4}$ baseline mixing ratio of the order of $100 \mathrm{ppb}$ away from coastline settlements. A more realistic methane enhancement of $30 \mathrm{ppb}$ might result in a change in the $\mathrm{C}_{1} /\left(\mathrm{C}_{2}+\mathrm{C}_{3}\right)$ ratio from 2131.31 to 1557.19 , falling well within the observed background variation. Importantly however, these simple calculations neglect the influence of bacterial oxidation in the water column. The capacity of microbes to remove dissolved $\mathrm{CH}_{4}$ from the water column may be considerable and methanotrophic bacteria are already thought to heavily mitigate ocean-atmosphere methane emissions (Crespo-Medina et al., 2014). For example, following the Deep Water Horizon drilling rig explosion on 20 April 2010 bacteria removed almost all of the methane released to the water column at a rate of $5900 \mathrm{nmol} \mathrm{L}^{-1}$ day $^{-1}$ (CrespoMedina et al., 2014).

The effect of bacterial oxidation on ethane and even propane emanating from the ocean is even less clear. However, ethanotrophic and propanotrophic bacteria are thought to be extant (Kinnaman et al., 2007), and many methanotrophes are also observed to cometabolize heavier hydrocarbons (Berthe-Corti and Fetzner, 2002). Kinnaman et al. (2007) also observed preferential metabolism of $\mathrm{C}_{2}-\mathrm{C}_{4}$ hydrocarbons over $\mathrm{CH}_{4}$ in incubated hydrocarbon-rich sediments, while Valentine et al. (2010) observed that propanotrophic and ethanotrophic bacteria were responsible for $70 \%$ of the oxygen depletion due to microbial activity in the pollution plume from the 2010 Deep Water Horizon drilling rig explosion in the Gulf of Mexico. Thus, there is considerable uncertainty as to what effect co-release of ethane or propane from hydrates into the water column will have on the atmosphere, making ethane an unreliable tracer for ocean-atmosphere $\mathrm{CH}_{4}$ emissions.

Changes in atmospheric $\delta^{13} \mathrm{C}$ in $\mathrm{CH}_{4}$ vs. V-PDB are similarly unreliable as a marker for ocean-atmosphere $\mathrm{CH}_{4}$ from sub-sea seeps because these are so close to ambient atmospheric background isotopic ratios. For example, using the values determined from the hydrates in this study in Table 2 and a background average from the offline samples of $-47.12 \%$, an increase in the atmospheric $\mathrm{CH}_{4}$ mixing ratio of $40 \mathrm{ppb}$ is needed to perturb the background ratio by more than the isotope analysis method precision, which averages $0.04 \%$. For a value of 3 times the precision, close to a $100 \mathrm{ppb}$ increase in methane due to hydrate emission would be required. The isotope analysis technique in this study is state-of-the-art, compared to a typical precision for $\delta^{13} \mathrm{C}$ in methane of $0.05 \%$ (Rice et al., 2001; Miller et al., 2002), but is only capable of detecting changes in $\delta^{13} \mathrm{C}$ resulting from relatively large changes in $\mathrm{CH}_{4}$ mixing ratios due to sub-sea emissions, i.e. larger than observed in our methane time series. Furthermore, as with ethane and propane, the isotopic ratio lacks specificity. $\delta^{13} \mathrm{C}$ in $\mathrm{CH}_{4}$ for hydrates ranges from $\approx-70$ to $-30 \%$ vs. V-PDB for biogenic and thermogenic hydrate types, respectively. This range overlaps with that of other sources, e.g. natural gas leaks or landfill emissions. Thus, $\delta^{13} \mathrm{C}$ in $\mathrm{CH}_{4}$ vs. V-PDB is strongly indicative of whether a source is biogenic or thermogenic in origin (Saunois et al., 2016), but cannot be used to distinguish between the reservoirs in which $\mathrm{CH}_{4}$ is stored, i.e. whether $\mathrm{CH}_{4}$ has been released from gas hydrates or sub-sea hydrocarbon seeps or land-based hydrocarbon seeps.

While both isotopic ratios and the $\mathrm{C}_{1} /\left(\mathrm{C}_{2}+\mathrm{C}_{3}\right)$ ratio are not unique tracers, and even though sub-sea sources are not expected to perturb background atmospheric isotopic and light hydrocarbon composition except at relatively high emission rates, they can nevertheless be used as part of an integrated approach to constrain $\mathrm{CH}_{4}$ sources, e.g. in multispecies inverse modelling (Thompson et al., 2018). Furthermore, both parameters are of considerable use in the analy- 
sis of global and regional trends in $\mathrm{CH}_{4}$ (e.g. Fisher et al., 2011; Dalsøren et al., 2018). The main limitation revealed by this study is practicality for constraining the relatively small ocean-atmosphere fluxes. The highly sensitive techniques used here require offline analysis of flask samples (see Sect. 2.3) in order to yield high analytical precision. Consequently, it is not feasible to obtain samples at every possible location or point in time. The collection of samples for analysis of isotopic and light hydrocarbon composition from subsea sources very likely requires a priori knowledge of a seep site location, and even then, there is no guarantee that measurements are highly sensitive to the location of the research vessel. However, with enough samples collected at a known seep site, changes in the atmospheric isotopic composition and $\mathrm{C}_{1} /\left(\mathrm{C}_{2}+\mathrm{C}_{3}\right)$ ratio could be used to quantify a flux.

\section{Conclusions}

We have presented long-term, high-resolution $\mathrm{CH}_{4}$ atmospheric mixing ratios from measurements at the Zeppelin Mountain Observatory and the RV Helmer Hanssen. We have also analysed additional trace gases (ethane, propane, and $\mathrm{CO}_{2}$ ) and isotopic composition in offline samples collected at the Helmer Hanssen, and modelled air mass trajectories with FLEXPART.

According to the data from Zeppelin, the trend of an increasing $\mathrm{CH}_{4}$ mixing ratio since 2005 continued in 2017, increasing on average by ca. 8 ppb after 2010. Atmospheric $\mathrm{CH}_{4}$ mixing ratios in the Arctic are highly variable, with baseline excursions of $\sim 30 \mathrm{ppb}$ being commonplace. With our dataset we are able to attribute all but one of the observed large excursions ( $>10 \mathrm{pbb}$ ) in background $\mathrm{CH}_{4}$ observed over different locations of the Arctic Ocean in June 2014-December 2016 to land-based sources (wetlands, anthropogenic emissions, biomass burning) by combining data from emission inventories and an atmospheric transport model. We also observe high correlations between models and observations on a monthly basis (up to $R^{2}=0.8$ ). In this context the large excursion in $\mathrm{CH}_{4}$ occurring during measurements along the coast of North Svalbard in August 2014 is unique and there is good evidence that we observed an ocean-atmosphere methane flux of up to $26 \mathrm{nmol} \mathrm{m}^{-2} \mathrm{~s}^{-1}$. This result agrees well with previous constraints on oceanatmosphere fluxes (Myhre et al., 2016; Pisso et al., 2016) and demonstrates the importance of long-term measurements in the region for assessing in-depth processes; i.e. the excursion from the background $\mathrm{CH}_{4}$ mixing ratio is only unique in the broader context of a time series where every other excursion is well explained.

We also found that neither co-emitted light hydrocarbons (ethane/propane) nor the $\delta^{13} \mathrm{C}$ isotopic ratio of $\mathrm{CH}_{4}$ are unique tracers for ocean-atmosphere emission from sub-sea seeps and hydrates, further demonstrating that identifying ocean-atmosphere $\mathrm{CH}_{4}$ emission sources is only possible via careful analysis of measurement data, combining both ocean and atmospheric measurements and analysis. Nevertheless, with a priori knowledge of the location of an ocean source, light hydrocarbon and isotopic composition may be useful for the quantification of fluxes if the flux is large enough. That is, atmospheric $\delta^{13} \mathrm{C}-\mathrm{CH}_{4}$ and $\mathrm{C}_{1} /\left(\mathrm{C}_{2}+\mathrm{C}_{3}\right)$ ratios are potentially more useful for quantification of fluxes from strong, known sources rather than the identification of new or potentially very small sources.

Finally, the fluxes we (and others) determined for sub-sea seep and hydrate derived ocean-atmosphere $\mathrm{CH}_{4}$ emissions are trivial compared to the global $\mathrm{CH}_{4}$ budget, even if extrapolated to much larger areas. Nevertheless, the Arctic is changing rapidly in response to climate change, and changes in the flux over time could contribute to future warming; thus, our results are a baseline against which future oceanatmosphere $\mathrm{CH}_{4}$ emissions can be compared.

Data availability. All atmospheric data from Zeppelin and the RV Helmer Hanssen are publicly available on the EBAS database (http: //ebas.nilu.no, EBAS, 2018). The harmonized dataset of historic $\mathrm{CH}_{4}$ mixing ratio measurements is archived in the ICOS Carbon portal (https://doi.org/10.18160/vnx5-qxcb) (ICOS, 2018).

Supplement. The supplement related to this article is available online at: https://doi.org/10.5194/acp-18-17207-2018-supplement.

Author contributions. Trace gas measurements on Helmer Hanssen: $\mathrm{OH}, \mathrm{BF}, \mathrm{PJ}, \mathrm{ASi}, \mathrm{SV}$, JM; methane measurements at Zeppelin: OH, NS, CLM; trend calculation of methane at Zeppelin: TS, CLM; development of the gas hydrate sampling technique: NS; FLEXPART model runs: IP, ASt; emissions: SE, ASt; isotopic analysis: EGN, DL, RF; data analysis trace gases at Helmer Hanssen and flux calculations: SP; manuscript writing: SP; review of the manuscript: all.

Competing interests. The authors declare that they have no conflict of interest.

Acknowledgements. SOCA (Signals from the Arctic OCean to the Atmosphere), NILU's strategic initiative (SIS) project funded by the Research Council of Norway. MOCA (Methane Emissions from the Arctic OCean to the Atmosphere): Present and Future Climate Effects was funded by the Research Council of Norway, grant no. 225814. CAGE (Centre for Arctic Gas hydrate Environment and climate) research work was supported by the Research Council of Norway through its Centres of Excellence funding scheme grant no. 223259.

Edited by: Rupert Holzinger

Reviewed by: two anonymous referees 


\section{References}

Bernard, B. B., Brooks, J. M., and Sackett, W. M.: Natural gas seepage in the Gulf of Mexico, Earth Planet. Sc. Lett., 31, 48-54, 1976.

Berthe-Corti, L. and Fetzner, S.: Bacterial Metabolism of n-Alkanes and Ammonia under Oxic, Suboxic and Anoxic Conditions, Eng. Life Sci., 22, 299-336, 2002.

Bousquet, P., Ringeval, B., Pison, I., Dlugokencky, E. J., Brunke, E.G., Carouge, C., Chevallier, F., Fortems-Cheiney, A., Frankenberg, C., Hauglustaine, D. A., Krummel, P. B., Langenfelds, R. L., Ramonet, M., Schmidt, M., Steele, L. P., Szopa, S., Yver, C., Viovy, N., and Ciais, P.: Source attribution of the changes in atmospheric methane for 2006-2008, Atmos. Chem. Phys., 11, 3689-3700, https://doi.org/10.5194/acp-11-3689-2011, 2011.

Buck, A. L.: New equations for computing vapor pressure and enhancement factor, J. Appl. Meteorol., 20, 1527-1532, 1981.

Chylek, P., Folland, C. K., Lesins, G., Dubey, M. K., and Wang, M.: Arctic air temperature change amplification and the Atlantic Multidecadal Oscillation, Geophys. Res. Lett., 36, L14801, https://doi.org/10.1029/2009GL038777, 2009.

Cohen, J., Screen, J. A., Furtado, J. C., Barlow, M., Whittleston, D., Coumou, D., Francis, J., Dethloff, K., Entekhabi, D., and Overland, J.: Recent Arctic amplification and extreme mid-latitude weather, Nat. Geosci., 7, 627-637, 2014.

Crespo-Medina, M., Meile, C., Hunter, K., Diercks, A., Asper, V., Orphan, V., Tavormina, P., Nigro, L., Battles, J., and Chanton, J.: The rise and fall of methanotrophy following a deepwater oilwell blowout, Nat. Geosci., 7, 423-427, 2014.

Dalsøren, S. B., Myhre, C. L., Myhre, G., Gomez-Pelaez, A. J., Søvde, O. A., Isaksen, I. S. A., Weiss, R. F., and Harth, C. M.: Atmospheric methane evolution the last 40 years, Atmos. Chem. Phys., 16, 3099-3126, https://doi.org/10.5194/acp16-3099-2016, 2016.

Dalsøren, S. B., Myhre, G., Hodnebrog, Ø., Myhre, C. L., Stohl, A., Pisso, I., Schwietzke, S., Höglund-Isaksson, L., Helmig, D., and Reimann, S.: Discrepancy between simulated and observed ethane and propane levels explained by underestimated fossil emissions, Nat. Geosci., 11, 178-184, https://doi.org/10.1038/s41561-018-0073-0, 2018.

Dlugokencky, E., Bruhwiler, L., White, J., Emmons, L., Novelli, P. C., Montzka, S. A., Masarie, K. A., Lang, P. M., Crotwell, A., and Miller, J. B.: Observational constraints on recent increases in the atmospheric $\mathrm{CH}_{4}$ burden, Geophys. Res. Lett., 36, L18803, https://doi.org/10.1029/2009GL039780, 2009.

EBAS: Atmospheric data from Zeppelin and RV Helmer Hanssen, available at: http://ebas.nilu.no, last access: 22 November 2018.

Etminan, M., Myhre, G., Highwood, E., and Shine, K.: Radiative forcing of carbon dioxide, methane, and nitrous oxide: A significant revision of the methane radiative forcing, Geophys. Res. Lett., 43, 12614-12623, https://doi.org/10.1002/2016GL071930, 2016.

Faramawy, S., Zaki, T., and Sakr, A.-E.: Natural gas origin, composition, and processing: A review, J. Nat. Gas Sci. Eng., 34, 34-54, 2016.

Fisher, R. E., Sriskantharajah, S., Lowry, D., Lanoisellé, M., Fowler, C., James, R., Hermansen, O., Lund Myhre, C., Stohl, A., and Greinert, J.: Arctic methane sources: Isotopic evidence for atmospheric inputs, Geophys. Res. Lett., 38, L21803, https://doi.org/10.1029/2011GL049319, 2011.
Geissler, W. H., Gebhardt, A. C., Gross, F., Wollenburg, J., Jensen, L., Schmidt-Aursch, M. C., Krastel, S., Elger, J., and Osti, G.: Arctic megaslide at presumed rest, Sci. Rep.-UK, 6, 38529, https://doi.org/10.1038/srep38529, 2016.

Graves, C. A., Steinle, L., Rehder, G., Niemann, H., Connelly, D. P., Lowry, D., Fisher, R. E., Stott, A. W., Sahling, H., and James, R. H.: Fluxes and fate of dissolved methane released at the seafloor at the landward limit of the gas hydrate stability zone offshore western Svalbard, J. Geophys. Res.-Oceans, 120, 6185-6201, 2015.

Hartmann, D. L., Klein Tank, A. M. G., Rusticucci, M., Alexander, L. V., Brönnimann, S., Charabi, Y., Dentener, F. J., Dlugokencky, E. J., Easterling, D. R., Kaplan, A., Soden, B. J., Thorne, P. W., Wild, M., and Zhai, P. M.: Observations: Atmosphere and Surface, in: Climate Change 2013: The Physical Science Basis, Contribution of Working Group I to the Fifth Assessment Report of the Intergovernmental Panel on Climate Change, Cambridge University Press, Cambridge, UK and New York, NY, USA, 2013.

Hayhoe, K., Kheshgi, H. S., Jain, A. K., and Wuebbles, D. J.: Substitution of natural gas for coal: climatic effects of utility sector emissions, Climate Change, 54, 107-139, 2002.

Helmig, D., Rossabi, S., Hueber, J., Tans, P., Montzka, S. A., Masarie, K., Thoning, K., Plass-Duelmer, C., Claude, A., and Carpenter, L. J.: Reversal of global atmospheric ethane and propane trends largely due to US oil and natural gas production, Nat. Geosci., 9, 490-495, https://doi.org/10.1038/ngeo2721, 2016.

Höglund-Isaksson, L.: Bottom-up simulations of methane and ethane emissions from global oil and gas systems 1980 to 2012, Environ. Res. Lett., 12, 024007, https://doi.org/10.1088/17489326/aa583e, 2017.

Hu, F. S., Higuera, P. E., Duffy, P., Chipman, M. L., Rocha, A. V., Young, A. M., Kelly, R., and Dietze, M. C.: Arctic tundra fires: natural variability and responses to climate change, Front. Ecol. Environ., 13, 369-377, 2015.

ICOS Carbon Portal, Integrated Non- $\mathrm{CO}_{2}$ Observing System (INGOS), and Bergamaschi, P.: Ensemble of inverse modelling results of European $\mathrm{CH}_{4}$ emissions during 2006-2012, ICOS ERIC - Carbon Portal, https://doi.org/10.18160/vnx5-qxcb, 2018.

IPCC: Climate Change 2013: The Physical Science Basis, Contribution of Working Group I to the Fifth Assessment Report of the Intergovernmental Panel on Climate Change, edited by: Stocker, T. F., Qin, D., Plattner, G.-K., Tignor, M., Allen, S. K., Boschung, J., Nauels, A., Xia, Y., Bex, V., and Midgley, P. M., Cambridge University Press, Cambridge, UK and New York, NY, USA, 1535 pp., 2013.

Jakobsson, M., Mayer, L., Coakley, B., Dowdeswell, J. A., Forbes, S., Fridman, B., Hodnesdal, H., Noormets, R., Pedersen, R., and Rebesco, M.: The international bathymetric chart of the Arctic Ocean (IBCAO) version 3.0, Geophys. Res. Lett., 39, L12609, https://doi.org/10.1029/2012GL052219 2012.

Kinnaman, F. S., Valentine, D. L., and Tyler, S. C.: Carbon and hydrogen isotope fractionation associated with the aerobic microbial oxidation of methane, ethane, propane and butane, Geochim. Cosmochim. Ac., 71, 271-283, 2007.

Kirschke, S., Bousquet, P., Ciais, P., Saunois, M., Canadell, J. G., Dlugokencky, E. J., Bergamaschi, P., Bergmann, D., Blake, D. 
R., and Bruhwiler, L.: Three decades of global methane sources and sinks, Nat. Geosci., 6, 813-823, 2013.

Kort, E., Wofsy, S., Daube, B., Diao, M., Elkins, J., Gao, R., Hintsa, E., Hurst, D., Jimenez, R., and Moore, F.: Atmospheric observations of Arctic Ocean methane emissions up to 82 north, Nat. Geosci., 5, 318-321, https://doi.org/10.1038/ngeo1452, 2012.

Kretschmer, K., Biastoch, A., Rüpke, L., and Burwicz, E.: Modeling the fate of methane hydrates under global warming, Glob. Biogeochem. Cy., 29, 610-625, 2015.

Kvenvolden, K. A.: Methane hydrate - a major reservoir of carbon in the shallow geosphere?, Chem. Geol., 71, 41-51, 1988.

Mackay, J.: Pingo growth and collapse, Tuktoyaktuk Peninsula area, western Arctic coast, Canada: A long-term field study, Geogr. Phys. Quatern., 52, 271-323, 1998.

Marín-Moreno, H., Giustiniani, M., Tinivella, U., and Piñero, E.: The challenges of quantifying the carbon stored in Arctic marine gas hydrate, Mar. Petrol. Geol., 71, 76-82, 2016.

Mau, S., Römer, M., Torres, M. E., Bussmann, I., Pape, T., Damm, E., Geprägs, P., Wintersteller, P., Hsu, C.-W., and Loher, M.: Widespread methane seepage along the continental margin off Svalbard-from Bjørnøya to Kongsfjorden, Sci. Rep.-UK, 7, 42997, https://doi.org/10.1038/srep42997, 2017.

McGinnis, D. F., Greinert, J., Artemov, Y., Beaubien, S., and Wüest, A.: Fate of rising methane bubbles in stratified waters: How much methane reaches the atmosphere?, J. Geophys. Res.-Oceans, 111, C09007, https://doi.org/10.1029/2005JC003183, 2006.

Miller, B. R., Weiss, R. F., Salameh, P. K., Tanhua, T., Greally, B. R., Mühle, J., and Simmonds, P. G.: Medusa: A sample preconcentration and GC/MS detector system for in situ measurements of atmospheric trace halocarbons, hydrocarbons, and sulfur compounds, Anal. Chem., 80, 1536-1545, 2008.

Miller, J. B., Mack, K. A., Dissly, R., White, J. W., Dlugokencky, E. J., and Tans, P. P.: Development of analytical methods and measurements of ${ }^{13} \mathrm{C} /{ }^{12} \mathrm{C}$ in atmospheric $\mathrm{CH}_{4}$ from the NOAA Climate Monitoring and Diagnostics Laboratory Global Air Sampling Network, J. Geophys. Res.-Atmos., 107, ACH 11-1-ACH 11-15, https://doi.org/10.1029/2001JD000630, 2002.

Myhre, C. L., Ferré, B., Platt, S. M., Silyakova, A., Hermansen, O., Allen, G., Pisso, I., Schmidbauer, N., Stohl, A., and Pitt, J.: Extensive release of methane from Arctic seabed west of Svalbard during summer 2014 does not influence the atmosphere, Geophys. Res. Lett., 43, 4624-4631, 2016.

NILU: FLEXTRA Back trajectories, available at: https://www.nilu. no/projects/ccc/trajectories/, last access: 04 June 2018.

Nisbet, E., Dlugokencky, E., Manning, M., Lowry, D., Fisher, R., France, J., Michel, S., Miller, J., White, J., and Vaughn, B.: Rising atmospheric methane: 2007-2014 growth and isotopic shift, Glob. Biogeochem. Cy., 30, 1356-1370, 2016.

Pisso, I., Myhre, C. L., Platt, S., Eckhardt, S., Hermansen, O., Schmidbauer, N., Mienert, J., Vadakkepuliyambatta, S., Bauguitte, S., and Pitt, J.: Constraints on oceanic methane emissions west of Svalbard from atmospheric in situ measurements and Lagrangian transport modeling, J. Geophys. Res.-Atmos., 121, 14188-14200, https://doi.org/10.1002/2016JD025590, 2016.

Pohlman, J. W., Greinert, J., Ruppel, C., Silyakova, A., Vielstädte, L., Casso, M., Mienert, J., and Bünz, S.: Enhanced $\mathrm{CO}_{2}$ uptake at a shallow Arctic Ocean seep field overwhelms the positive warming potential of emitted methane, P. Natl. Acad. Sci. USA, 114, 5355-5360, https://doi.org/10.1073/pnas.1618926114, 2017.
Prinn, R. G., Weiss, R. F., Krummel, P. B., O’Doherty, S., Fraser, P., Muhle, J., Reimann, S., Vollmer, M., Simmonds, P. G., and Malone, M.: The ALE/GAGE/AGAGE Network, Massachusetts Institute of Technology, Cambridge, MA, USA, 2008.

Randerson, J. T., van der Werf, G., Giglio, L., Collatz, G. J., and Kasibhatla., P. S.: Global Fire Emissions Database, Version 4.1 (GFEDv4). ORNL DAAC, Oak Ridge, Tennessee, USA, available at: https://doi.org/10.3334/ORNLDAAC/1293, 2017.

Reeburgh, W. S.: Oceanic methane biogeochemistry, Chem. Rev., 107, 486-513, 2007.

Rice, A., Gotoh, A., Ajie, H., and Tyler, S.: High-precision continuous-flow measurement of $\delta^{13} \mathrm{C}$ and $\delta \mathrm{D}$ of atmospheric $\mathrm{CH}_{4}$, Anal. Chem., 73, 4104-4110, 2001.

Rigby, M., Prinn, R. G., Fraser, P. J., Simmonds, P. G., Langenfelds, R., Huang, J., Cunnold, D. M., Steele, L. P., Krummel, P. B., and Weiss, R. F.: Renewed growth of atmospheric methane, Geophys. Res. Lett., 35, L22805, https://doi.org/10.1029/2008GL036037, 2008.

Saunois, M., Bousquet, P., Poulter, B., Peregon, A., Ciais, P., Canadell, J. G., Dlugokencky, E. J., Etiope, G., Bastviken, D., Houweling, S., Janssens-Maenhout, G., Tubiello, F. N., Castaldi, S., Jackson, R. B., Alexe, M., Arora, V. K., Beerling, D. J., Bergamaschi, P., Blake, D. R., Brailsford, G., Brovkin, V., Bruhwiler, L., Crevoisier, C., Crill, P., Covey, K., Curry, C., Frankenberg, C., Gedney, N., Höglund-Isaksson, L., Ishizawa, M., Ito, A., Joos, F., Kim, H.-S., Kleinen, T., Krummel, P., Lamarque, J.-F., Langenfelds, R., Locatelli, R., Machida, T., Maksyutov, S., McDonald, K. C., Marshall, J., Melton, J. R., Morino, I., Naik, V., O’Doherty, S., Parmentier, F.-J. W., Patra, P. K., Peng, C., Peng, S., Peters, G. P., Pison, I., Prigent, C., Prinn, R., Ramonet, M., Riley, W. J., Saito, M., Santini, M., Schroeder, R., Simpson, I. J., Spahni, R., Steele, P., Takizawa, A., Thornton, B. F., Tian, H., Tohjima, Y., Viovy, N., Voulgarakis, A., van Weele, M., van der Werf, G. R., Weiss, R., Wiedinmyer, C., Wilton, D. J., Wiltshire, A., Worthy, D., Wunch, D., Xu, X., Yoshida, Y., Zhang, B., Zhang, Z., and Zhu, Q.: The global methane budget 2000-2012, Earth Syst. Sci. Data, 8, 697-751, https://doi.org/10.5194/essd-8-697-2016, 2016.

Serov, P., Vadakkepuliyambatta, S., Mienert, J., Patton, H., Portnov, A., Silyakova, A., Panieri, G., Carroll, M. L., Carroll, J., and Andreassen, K.: Postglacial response of Arctic Ocean gas hydrates to climatic amelioration, P. Natl. Acad. Sci. USA, 114, 62156220, https://doi.org/10.1073/pnas.1619288114, 2017.

Shakhova, N., Semiletov, I., Leifer, I., Sergienko, V., Salyuk, A., Kosmach, D., Chernykh, D., Stubbs, C., Nicolsky, D., and Tumskoy, V.: Ebullition and storm-induced methane release from the East Siberian Arctic Shelf, Nat. Geosci., 7, 64-70, 2014.

Simmonds, P., Manning, A., Cunnold, D., McCulloch, A., O’Doherty, S., Derwent, R., Krummel, P., Fraser, P., Dunse, B., and Porter, L.: Global trends, seasonal cycles, and European emissions of dichloromethane, trichloroethene, and tetrachloroethene from the AGAGE observations at Mace Head, Ireland, and Cape Grim, Tasmania, J. Geophys. Res.-Atmos., 111, D18304, https://doi.org/10.1029/2006JD007082, 2006.

Sloan Jr., E. D.: Clathrate Hydrates of Natural Gases, revised and expanded, CRC Press, Boca Raton, FL, USA, ISBN 9780849390784, 1998.

Smith, A. J., Mienert, J., Bünz, S., and Greinert, J.: Thermogenic methane injection via bubble transport into the upper Arc- 
tic Ocean from the hydrate-charged Vestnesa Ridge, Svalbard, Geochem. Geophy. Geosy., 15, 1945-1959, 2014.

Spahni, R., Wania, R., Neef, L., van Weele, M., Pison, I., Bousquet, P., Frankenberg, C., Foster, P. N., Joos, F., Prentice, I. C., and van Velthoven, P.: Constraining global methane emissions and uptake by ecosystems, Biogeosciences, 8, 1643-1665, https://doi.org/10.5194/bg-8-1643-2011, 2011.

Stocker, B. D., Spahni, R., and Joos, F.: DYPTOP: a costefficient TOPMODEL implementation to simulate sub-grid spatio-temporal dynamics of global wetlands and peatlands, Geosci. Model Dev., 7, 3089-3110, https://doi.org/10.5194/gmd7-3089-2014, 2014.

Stohl, A., Forster, C., Frank, A., Seibert, P., and Wotawa, G.: Technical note: The Lagrangian particle dispersion model FLEXPART version 6.2, Atmos. Chem. Phys., 5, 2461-2474, https://doi.org/10.5194/acp-5-2461-2005, 2005.

Stohl, A., Berg, T., Burkhart, J. F., Fjǽraa, A. M., Forster, C., Herber, A., Hov, Ø., Lunder, C., McMillan, W. W., Oltmans, S., Shiobara, M., Simpson, D., Solberg, S., Stebel, K., Ström, J., Tørseth, K., Treffeisen, R., Virkkunen, K., and Yttri, K. E.: Arctic smoke - record high air pollution levels in the European Arctic due to agricultural fires in Eastern Europe in spring 2006, Atmos. Chem. Phys., 7, 511-534, https://doi.org/10.5194/acp-7511-2007, 2007.

Stohl, A., Klimont, Z., Eckhardt, S., Kupiainen, K., Shevchenko, V. P., Kopeikin, V. M., and Novigatsky, A. N.: Black carbon in the Arctic: the underestimated role of gas flaring and residential combustion emissions, Atmos. Chem. Phys., 13, 8833-8855, https://doi.org/10.5194/acp-13-8833-2013, 2013.

Stohl, A., Aamaas, B., Amann, M., Baker, L. H., Bellouin, N., Berntsen, T. K., Boucher, O., Cherian, R., Collins, W., Daskalakis, N., Dusinska, M., Eckhardt, S., Fuglestvedt, J. S., Harju, M., Heyes, C., Hodnebrog, Ø., Hao, J., Im, U., Kanakidou, M., Klimont, Z., Kupiainen, K., Law, K. S., Lund, M. T., Maas, R., MacIntosh, C. R., Myhre, G., Myriokefalitakis, S., Olivié, D., Quaas, J., Quennehen, B., Raut, J.-C., Rumbold, S. T., Samset, B. H., Schulz, M., Seland, Ø., Shine, K. P., Skeie, R. B., Wang, S., Yttri, K. E., and Zhu, T.: Evaluating the climate and air quality impacts of short-lived pollutants, Atmos. Chem. Phys., 15, 10529-10566, https://doi.org/10.5194/acp-15-105292015, 2015.

Taylor, K. E.: Summarizing multiple aspects of model performance in a single diagram, J. Geophys. Res.-Atmos., 106, 7183-7192, 2001.

Thompson, R. L., Sasakawa, M., Machida, T., Aalto, T., Worthy, D., Lavric, J. V., Lund Myhre, C., and Stohl, A.: Methane fluxes in the high northern latitudes for 2005-2013 estimated using a Bayesian atmospheric inversion, Atmos. Chem. Phys., 17, 35533572, https://doi.org/10.5194/acp-17-3553-2017, 2017.

Thornton, B. F., Geibel, M. C., Crill, P. M., Humborg, C., and Mörth, C. M.: Methane fluxes from the sea to the atmosphere across the Siberian shelf seas, Geophys. Res. Lett., 43, 5869$5877,2016$.
United Nations Framework Convention on Climate Change (UNFCCC): Greenhouse Gas Inventory Data - Detailed data by Party, available at: http://di.unfccc.int/detailed_data_by_party, last access: 24 May 2018.

Valentine, D. L., Kessler, J. D., Redmond, M. C., Mendes, S. D., Heintz, M. B., Farwell, C., Hu, L., Kinnaman, F. S., Yvon-Lewis, S., and Du, M.: Propane respiration jump-starts microbial response to a deep oil spill, Science, 330, 208-211, 2010.

Wallmann, K., Riedel, M., Hong, W.-L., Patton, H., Hubbard, A., Pape, T., Hsu, C., Schmidt, C., Johnson, J. E., and Torres, M.: Gas hydrate dissociation off Svalbard induced by isostatic rebound rather than global warming, Nat. Commun., 9, 83, https://doi.org/10.1038/s41467-017-02550-9, 2018.

Wanninkhof, R.: Relationship between wind speed and gas exchange over the ocean revisited, Limnol. Oceanogr.-Meth., 12, 351-362, 2014.

Wanninkhof, R., Asher, W. E., Ho, D. T., Sweeney, C., and McGillis, W. R.: Advances in quantifying air-sea gas exchange and environmental forcing, Annu. Rev. Mar. Sci., 1, 213-244, https://doi.org/10.1146/annurev.marine.010908.163742, 2009.

Westbrook, G. K., Thatcher, K. E., Rohling, E. J., Piotrowski, A. M., Pälike, H., Osborne, A. H., Nisbet, E. G., Minshull, T. A., Lanoisellé, M., and James, R. H.: Escape of methane gas from the seabed along the West Spitsbergen continental margin, Geophys. Res. Lett., 36, L15608, https://doi.org/10.1029/2009GL039191, 2009.

Wiesenburg, D. A., and Guinasso Jr., N. L.: Equilibrium solubilities of methane, carbon monoxide, and hydrogen in water and sea water, J. Chem. Eng. Data, 24, 356-360, 1979.

Winkelmann, D., Jokat, W., Niessen, F., Stein, R., and Winkler, A.: Age and extent of the Yermak Slide north of Spitsbergen, Arctic Ocean, Geochem. Geophy. Geosy., 7, Q06007, https://doi.org/10.1029/2005GC001130, 2006.

WMO: World Meteorological Office (WMO) Statement on the state of the global climate in 2017, available at: https://library.wmo. int/opac/doc_num.php?explnum_id=4453 (last access:15 June 2018), 2017.

Worden, J. R., Bloom, A. A., Pandey, S., Jiang, Z., Worden, H. M., Walker, T. W., Houweling, S., and Röckmann, T.: Reduced biomass burning emissions reconcile conflicting estimates of the post-2006 atmospheric methane budget, Nat, Commun., 8, 2227 ,https://doi.org/10.1038/s41467-017-02246-0, 2017.

Yttri, K. E., Lund Myhre, C., Eckhardt, S., Fiebig, M., Dye, C., Hirdman, D., Ström, J., Klimont, Z., and Stohl, A.: Quantifying black carbon from biomass burning by means of levoglucosan - a one-year time series at the Arctic observatory Zeppelin, Atmos. Chem. Phys., 14, 6427-6442, https://doi.org/10.5194/acp14-6427-2014, 2014. 